\title{
The effectiveness of using infographics on academic achievement: A meta-analysis and a meta-thematic analysis
}

\author{
Şenel Elaldı ${ }^{1}$ and Taner Çifçi ${ }^{2}$ \\ ${ }^{1}$ Cumhuriyet University, Education Faculty, Turkey (ORCID: 0000-0002-2057-7136) \\ ${ }^{2}$ Cumhuriyet University, Education Faculty, Turkey (ORCID: 0000-0003-0780-4207)
}

\begin{abstract}
This study aims to reinterpret the findings of the studies investigating the effectiveness of using infographics on academic achievement. A mixed methods research design including both quantitative and qualitative sections was adopted on the use of infographics in education. For this purpose, a meta-analysis of 12 empirical studies on the effect of using infographics on academic achievement in education carried out during the period from 2016 to 2021 was conducted. Some moderator analyses such as school grades, implementation period and school subjects in which infographics were used were also conducted to reveal the effectiveness of using infographics in education. The findings suggest that using infographics in education has a positive effect on academic achievement and the effect is at a large level $(g=1.599)$. In terms of moderator analyses, the academic achievement changed according to implementation periods of infographics. The highest effect size was in the " $4-5$ weeks" group $(g=1.343)$. The meta-thematic aspect of this study revealed three dimensions of infographics as cognitive contributions, challenges in using and development of infographics and, suggestions for application. More empirical studies are suggested to test the expressed power of infographics as an effective visual communication tool and teaching material.
\end{abstract}

Keywords: Infographic; Infographics in education; Academic achievement; Meta-analysis

Article History: Submitted 29 June 2021; Revised 11 November 2021; Published online 7 December 2021

\section{Introduction}

Educators need methods that engage and assist students in learning, remembering and applying new concepts (Ermis, 2008). The use of visual framework is one of the primary opportunities for educators and researchers to develop and expand knowledge, skills and abilities (Reyes, 2011; Sundeen, 2007). Visualization is important for disseminating information quickly, effectively and accurately in different environments such as research, education and journalism (Islamoglu et al., 2015; Nesbit \& Adesope, 2006). Today, with the development of many visualization tools in our digital society, these tools have become much easier to use and more user-friendly than years ago (Toth, 2013). Via various visualization tools and technology, the learning activities carried out in the classroom environment have gone beyond the walls of the classroom (Ozdamli et al., 2016; Smiciklas, 2012; Toth, 2013).

Address of Corresponding Author

Şenel Elaldı, PhD, Cumhuriyet University, Education Faculty, 58140, Sivas, Turkey.

$\triangle$ snlelaldi@gmail.com

How to cite: Elaldı, Ş. \& Çifçi, T. (2021). The effectiveness of using infographics on academic achievement: A meta-analysis and a metathematic analysis. Journal of Pedagogical Research, 5(4), 92-118. https:/ / doi.org/10.33902/JPR.2021473498 
As one of the increasingly popular data visualization tools, infographics, information graphics, enable users to quickly provide an overview of almost any topic and visualize the big picture of a complex idea or content (Lamb et al., 2014; Moorefield-Lang, 2011). These tools are important ways of presenting complex data and communicating insights visually (Polman \& Gebre, 2015). The term "infography" was originally used for information graphics in a media context, but now refers to the larger visual messaging tools used to present information (Nuhoğlu-Kibar \& Akkoyunlu, 2014). Furthermore, nowadays, the use of the word infographic has evolved to include a new definition that combines data visualizations, drawings, text, and images in a format that tells a story (Krum, 2014). Therefore, based on this definition, it is possible to say that infographics have three stages: a stage of visualized information or data; a design stage that includes illustrations, text and images; and a storytelling stage by combining previous elements on a single canvas. Visualization is associated with the presentation way of data sets that are presented in charts, graphs, maps and other graphic forms. On the other hand, the design phase includes text, illustrations and images as part of the integrity, as well as some graphic design options such as color, font and spacing as indicators of communicative qualities (Abilock \& Williams 2014). The storytelling stage involves expressing the insights or messages transmitted through visual elements using rhetorical techniques such as juxtaposition or metaphors (Islamoglu et al., 2015; Krum, 2014). Since being a means to simplify and summarize complex information in an easy-tounderstand way, the main purpose of infographics is to provide a clear, and easy-to-understand explanation of the information shared with the reader (Lankow et al., 2012; Reavy, 2003). In this case, the synthesis of quantitative research that clarifies a broader picture of the effectiveness of infographics in various learning environments becomes theoretically important.

\subsection{Literature Review}

In today's society, an information explosion and an increasing complexity of the subject matters in many fields have become widespread due to the easy access to readily available information (Keller \& Tergan,2005). Hence, a change in producing, consuming and distributing information has gained importance to meet the requirements of the age (Ware, 2012). Nowadays, the fact that information is "at the tip of the fingers" provides convenience in obtaining, structuring, using and disseminating information. In this regard, information can be visualized to make large amounts of information easily accessible to users. Thereby, understanding the relationships between information items and visually searching the relevant information can be achieved (Keller \& Tergan, 2005). In this respect, information design has become much more important and the use of data visualization and infographics is increased in order to quickly deliver more comprehensible information (Lamb \& Johnson, 2014; Smiciklas, 2012) especially in the fields of education, science, and visual communication (Davis \& Quinn, 2014; Polman \& Gebre, 2015).

The fact that education programs are expected to follow the needs of the age and renew the curriculum by determining the relevant needs (Uyan Dur, 2014). To this end, it is very important to choose suitable materials prepared for educational purposes. Choosing the materials in a way that is appropriate to the subject matter, understandable and remarkable will enable the information to be explained easily and comprehensibly without wasting too much time. On the other hand, besides organizing information correctly, presented it with an effective and creative visual design or with storytelling, or with efficient use of technology will affect student development and learning process positively (Ru \& Ming, 2014; Toth, 2013). In line with the nature of this study, it is said that infographics are visual materials used in education for learners and teachers to transfer information about a specific subject more effectively and faster and support conceptual understanding through displaying data including colors and images (Oetting, 2015; Smiciklas, 2012). 


\subsubsection{Infographics in education}

Infographics hold an important place in education due to their illustration of the complex information in a compact form. Thanks to this feature of infographics, they allow teachers to prepare ready various learning activities, to summarize the unit, to engage learners with the course contents, and to teach the lesson more interactively and more productively (Vanichvasin, 2013). In education, infographics are defined as educational resources that interpret the topic in the form of a unique and compelling story that includes introduction, key content, and conclusion sections (Bradshaw \& Porter, 2017). Furthermore, infographics can be used in education as an alternative tool to enhance and share information in diverse digital channels, to develop students' visual communication skills such as creating and presenting visual knowledge, and to interpret and comprehend the subject (Smiciklas, 2012). Infographics are also utilized in a course as a communication tool to provide learners with discussions and, to share their ideas with their peers online via social media or in the classroom (MacQuarrie, 2012). Since infographics increase conceptual understanding and raise the chance of sharing information across a wide variety of digital ways, they enable learners to activate their verbal and visual-pictorial channels and contribute to their development of meaningful learning (Krum, 2014; Schrock, 2014; Smiciklas, 2012).

Some latest studies on using Bloom's taxonomy to support visual learning skills (i.e., Arneson \& Offerdahlin, 2018; Byrd, 2019) have emphasized the importance of selecting an assistive educational approach that includes the utilization of visualized technology in education. This is because we cannot ignore the fact that today's students are very intertwined with technology and learn many things through technology by visualizing them (Gangwer, 2015; Shatri \& Buza, 2017). As Wulandari (2013) states, the generation that was born and raised in the era of dominance of technology use and called digital native generation is familiar in the use and operation of technologic tools. Furthermore, this generation is different from previous generations in terms of some learning characteristics such as seeking information and the ability to use technology (Helsper \& Eynon, 2010). For this reason, infographics are used in education to present information visually to these students, as they provide comprehensive information in any field such as showing the relationship between different concepts, transmitting the event or process, presenting a subject's content and summarizing the learned topics (Meeusah \& Tangkijviwat, 2013). In this sense, positive influence of infographics on students' learning quality has been concluded in some studies in the literature (i.e., Matrix \& Hodson; 2014; Schulten, 2012; Vanichvasin, 2013). Likewise, Naparin and Saad (2017), who investigated the application of infographics in education, emphasized the advantage of using infographics over traditional method of teaching in terms of enhancing students' understanding and students' showing high performance in the exams. In parallel with these all, in Fadzil's (2018) study, it was concluded that infographics enhanced students' engagement to learn better through technology. On the other hand, other advantages of infographics in education are outlined as: easily improving learners' memory retention and comprehension (Vanichvasin, 2013), developing synthesizing and critical thinking skills (Islamoglu et al., 2015), improving the comprehension of reading and writing (Akdal, 2019; Davis \& Quinn, 2014; Meacham, 2015; Saadah, 2019), simplifying the complex subjects such as history, mathematics, and science (Davis \& Quinn, 2014), developing learners' life skills, teamwork skills, and systematic thinking (Uyan Dur, 2014), improving learners' hands-on learning, problem-solving, creative thinking and engagement (Davidson, 2014; Islamoglu et al., 2015; Meacham, 2015),

Although infographics have many advantages in facilitating learning, instructors taking the use of infographics into consideration as a course material or assignment should be aware of the challenges and difficulties that both instructors and students will face in terms of transferring information in a comprehensible and attractive manner (Howes \& Stevenson, 2013). Toth (2013) found that students had difficulties with visual design elements due to the fact that they were unaware that considerable effort was required to create infographics, in other words, to transfer 
large amounts of data into a purposeful, visual representation. Thus, the inability of students to blend too much information and to present it visually may obstruct the purpose of the message by causing misinformation and confusion (Cano, 2011; Moorefield-Lang, 2011). These challenges become even more complicated by time constraints when students are given homework to create an infographic within a fixed time (Chicca \& Chunta, 2020; Howes \& Stevenson, 2013; Toth, 2013). Therefore, Howes and Stevenson (2013) suggested that the time allocated to reveal the creativity aspects of students while creating infographics should be carefully considered and monitored. In addition, it should also be noted that infographics are not a straightforward genre that any students can create directly. Some specific and distinct skill sets are required to create them (Gonzalez, 2018).

On the other side, there is always a debate on what makes infographics well designed stemming from the criticism against poorly designed and misleading infographics. It is due to the different presentation styles of the data presented in the infographics. Some designers present data in technical ways while others prefer more narrative and illustrative ways of data storytelling (Quispel et al., 2018). In this sense, it should be taken into account that the main function of an infographic is to transfer comprehensible information accurately, but also to transfer it in an attractive way (Bateman et al., 2010). Thus, blending data with design is important for the comprehensibility and attractiveness of infographics (Smiciklas, 2012). In designing infographics used in education, one must consider a strategy and target audience to provide students with an effective educational experience without seeking additional resources. Thus, effective infographics in an educational setting as mind maps, content summaries, or study tools are expected to transfer the essence or basics of a message without requiring students to thoroughly read the relevant text (Dunlap \& Lowenthal, 2016; Ware, 2012). Accordingly, instructors or designers should focus on the concept rather than worrying about creating infographic texts (EDUCAUSE Learning Initiative, 2013). It is of primary importance that instructors are more considerate of students' literacy needs in the evaluation, selection and use of pedagogical materials (Gonzalez, 2018). Then, it is necessary to have confidence, knowledge, experience and specific skills in design and creating infographics (Shahin, 2020; Stones \& Gent, 2015).

\subsubsection{Contribution of previous studies to current research}

The research on the educational use of infographics is still not fully sufficient in terms of synthesizing its educational and pedagogical aspects; and it is seen that most of the studies mentioned above and existing in the literature but not cited here have existed as qualitative research examining various significant aspects of infographics (i.e., Cemelelioğlu Altın, 2018; Dunlap \& Lowenthal, 2016; Gallicano et al., 2014; Gonzalez, 2018). Furthermore, as understood from the relevant literature, while there is a growing number of experimental research conducted especially in the last six years, there is no meta-analysis research to examine and synthesize the experimental evidences. On the other hand, only one study was found synthesizing qualitative research. The study conducted by Naparin and Saad (2017) investigated infographics in various areas. The researchers used content analysis in qualitative dimension and reviewed 55 articles published from 2004 to 2016 on infographics and discussed the results. Therefore, a gap regarding the lack of meta-analysis studies and systematic reviews on specifically the use of infographics in education in the literature has emerged. In this context, it is thought that this research will make a significant contribution to the literature as it is a meta-analysis of quantitative recent studies that have been conducted in the field of education to question the effectiveness of infographics on academic achievement. Moreover, with this two-dimensional study designed as a meta-analysis and a meta-thematic analysis, it is aimed to contribute to the relevant literature and to pioneer new studies to be carried out in this context. Therefore, it is expected that this study will contribute to understanding the role of infographics in education by presenting a unique and integrative framework. What's more, a meta-thematic dimension to the study enabled to combine common views obtained from qualitative research on the use of infographic in education. On the other 
hand, through moderator analyses, we found out whether the effect of the use of infographics on academic achievement changed in terms of school grades, implementation periods and school subjects in which infographics were used.

\subsection{Variables of the Study}

In the meta-analytic review of this study, moderator variables were also selected to reveal if the overall effect size of the use of infographics in education was related to some features of the studies included in the meta-analysis. In this regard, in the coding process, it was observed that the studies have some common characteristics such as teaching infographics in different grades, duration of the use of infographics in experimental process, subject areas of instruction, number of students engaged in the use of infographics (class sizes, and kinds of infographics like visually intensive and text-intensive infographics (Çifçi, 2016; Yılmaz et al., 2019). On the other hand, many research included in the meta-analysis have suggested for further studies that the use of infographics in education should be addressed at different grades (i.e., Akdal, 2019; Alrwere, 2017; Alshehri \& Ebaid, 2016; Çifçi, 2016; Kokoz, 2019; Yıldırım, 2018), different intervention duration (i.e., Caka, 2018), and different subject areas (i.e., Çifçi, 2016; Kokoz, 2019; Ozel, 2019; Yıldırım, 2018). Thus, taking these into consideration, the moderator variables of this study are identified as school grades that refers to the education stages categorized as Primary School, Secondary School, High School and University; implementation period that refers to the durations during which infographic implementations were implemented. The periods of time were categorized as 2-3, 4-5, 6-7, 8 and above weeks, and unspecified; and, school subjects related to subject areas of teaching in which infographics were used. These subjects were categorized as Geography, Science, Social Sciences, English Language Teaching, Mathematics and Information Technologies.

\subsection{Objectives of the Study}

This study aims to analyze and reinterpret the empirical studies that were conducted independently from each other through meta-analysis in order to determine the effectiveness of using infographics in education. In this regard, the primary aim of this study was to examine the general impact of infographics on academic achievement. The effectiveness of using infographics on achievement refers to the post-test scores of the experimental and control groups. On the other hand, this study also aims to provide in-depth information regarding infographics and their use in education through meta-thematic analysis. In this context, it should be noted that both quantitative and qualitative methods are included in the study. The following research questions were addressed in this study:

1. What level of the average/overall effect size do the studies conducted between 2016 and 2021 have?

2. What are the views of participants on the use of infographics in education within the context of thematic review in accordance with document analysis?

\section{Method}

\subsection{Methodology in the Quantitative Part}

It is a mixed method research in which both quantitative and qualitative methods are used together to determine the effectiveness of inclusion practices. According to methodologists, combining quantitative and qualitative research develops a more complete and complementary understanding by increasing the power of each approach (Creswell \& Plano Clark, 2011). The methodological process and findings of the study are discussed separately in quantitative and qualitative parts. While the first part explains the meta-analytical research used to consolidate the findings of quantitative studies on infographics, the second part expounds the meta-thematic analysis part of the studies carried out qualitatively on the same subject. 


\subsubsection{Meta-analysis process of the study}

In the quantitative aspect, on account of identifying the effectiveness of using infographics on achievement, the relevant studies available in the literature were reached and analyzed through meta-analysis.

\subsubsection{Data collection process of the study}

The studies on infographics were searched in the databases of Web of Science, Google Scholar, the Higher Education Thesis and Dissertation Center of Turkish Council (YOK), ProQuest Dissertation \& Thesis Global, Taylor \& Francis Online, Scopus (A\&I), Ebscohost-Eric, ScienceDirect, Wiley Online Library Full Collection, Springer LINK, and Sage Journals Online. The concepts of "infographics," "use of infographics", "visual tools," "educational infographics," "infographics and effectiveness", and "infographics and academic achievement" were used to reach the relevant studies within the databases. As a result of the search process, we reached the studies investigating the effectiveness of using infographics in education during the period of 2016-2021.

\subsubsection{Inclusion and exclusion criteria of the study}

The inclusion criteria established to examine the effectiveness of using infographics in education included: (1) Since it has been revealed that experimental studies on the use of infographic in education have been conducted in recent years, the research has been limited to only six years. (2) The studies that were published English and non-English (Turkish) in international refereed journals, books and book chapters and unpublished theses and dissertations carried out in the period of 2016-2021 were scanned. (3) Empirical studies in which the experimental and control groups were used in the pre-test-post-test control group model and that include sample sizes, means and standard deviations or t-test values were considered as the inclusion criteria. The flow chart for literature review is given in Figure 1 in line with the PRISMA Flow Diagram (Moher, Liberati, Tetzlaff, Altman \& The PRISMA Group, 2009). On the other hand, studies that did not meet the inclusion criteria were excluded from the research (See Figure 1).

As given in Figure 1, as a result of scanning the databases aforementioned, a total number of 173 studies were reached. Due to not meeting the inclusion criteria of the study and not including full texts, 141 of these studies were disqualified from the analysis. On the examination of the other 32 studies in terms of their suitability and quality, 13 studies that were found to have irrelevant topics, not including measurements on academic achievement or to be duplications were also excluded. Finally, 7 studies that did not contain the data required for statistical calculations $(x, d f, n)$ which are necessary for meta-analysis excluded from the study. Therefore, a total number of 12 publications consistent with the inclusion criteria and the research problem were included. It was determined that the total sample size of the studies consisted of 990 participants from experimental $(n=483)$ and control $(n=507)$ groups.

\subsubsection{Coding process}

The studies within the scope of the research were subject to a coding process to understand whether they meet the inclusion criteria of meta-analysis. In this regard, to put forth the reliability and validity of the study, a detailed coding form containing the general characteristics of the research included in the study was developed before the statistical analysis was carried out (Bangert- Drowns \& Rudner, 1991). The coding form had two sections. The first section included information about the identity of the study such as the author name, study year, study type, study field and, class / grade. The second section included information such as population size, effect size values and, application periods (see Appendix 1). Furthermore, during the coding process, two researchers as coders examined all the review research and made their evaluations in the form separately. Then, to reveal the inter- rater reliability between the coders, in other words, to reveal the consistency in the form, Miles and Huberman's (1994) formula (consensus/(consensus + dissensus) $\times 100$ ] was used and a consensus of $100 \%$ agreement was reached. 
Figure 1

Literature Flowchart (PRISMA-P flowchart)

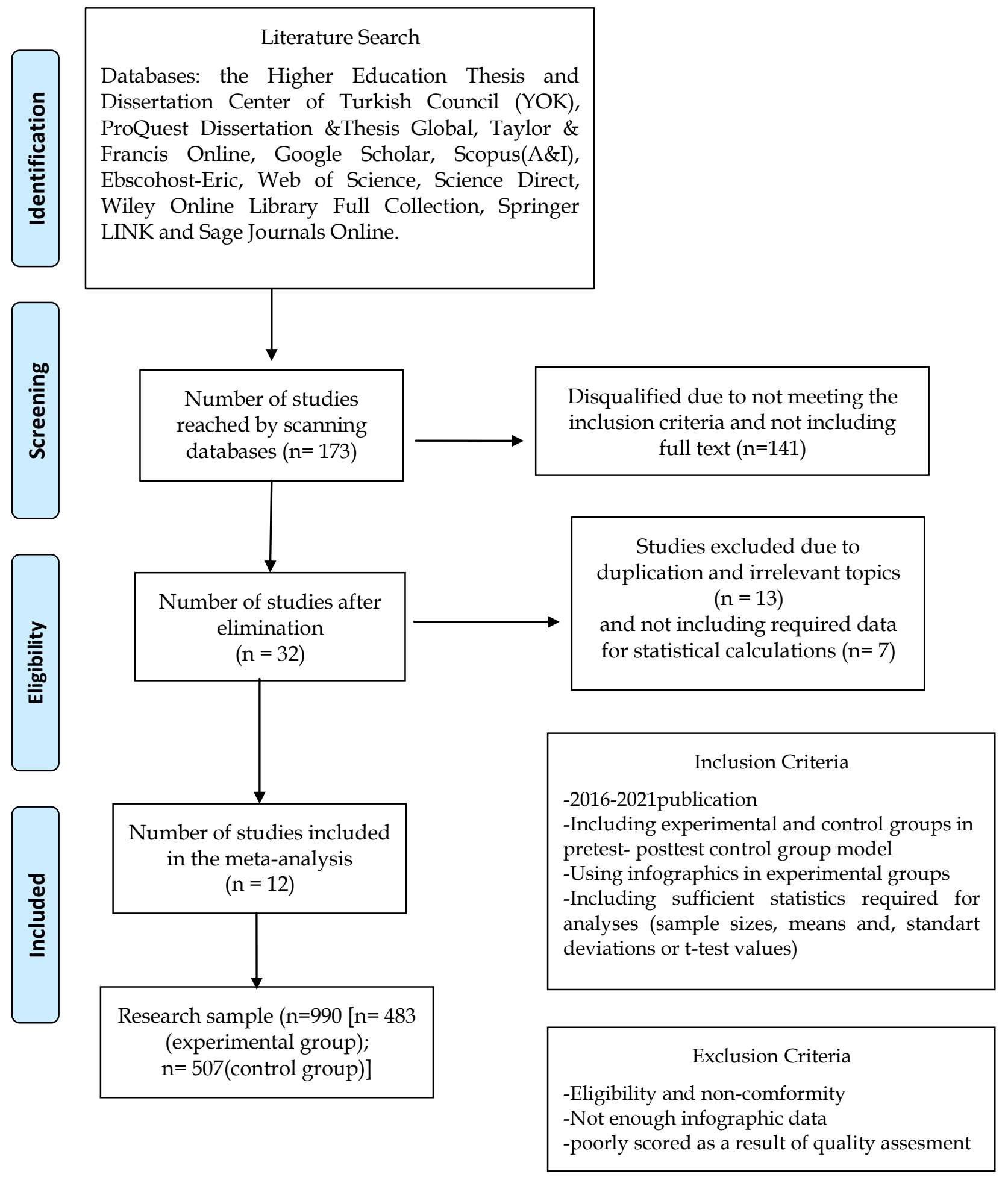

\subsubsection{Data analysis process}

After determining the data for meta-analysis, they were coded and tabulated through Microsoft Office Excel program and percentage and frequency calculations of the relevant findings were made. For the effect sizes, heterogeneity test and publication bias calculations of each study, CMA 3.0 software (Borenstein \& Rothstein, 1999) was used. The effect sizes of the studies analyzed in this research was interpreted according to Cohen's (1992) guidelines suggesting that $\leq 0.20$ is a small effect size, 0.50 is a moderate effect size and $\geq 0.80$ is a large effect size. 


\subsubsection{Heterogeneity and effect sizes}

Heterogeneity test (Q-statistics) showing the Chi-square $\left(\chi^{2}\right)$ heterogeneity test with degree of freedom (k-1) was used to test whether there is heterogeneity among the studies. Besides, $\mathrm{I}^{2}$ value, an indicator of heterogeneity, (Petticrew \& Roberts, 2006) was calculated and found to be 95.966 which indicates a high level of heterogeneity according to the Higgins and Thompson (2002) classification. The effect size, which is considered to be an important unit in a meta-analysis, is a value that reflects the correlation between variables or the size of the difference between groups (Borenstein et al., 2009). The Hedges formula, which reveals the standardized mean difference between groups, was used for effect size estimation (Hedges \& Olkin, 1985). In the meta-analysis studies, in order to calculate the effect size of the data, fixed effects model (FEM) and random effects model (REM) are used (Borenstein et al., 2009). While the studies in the FEM do not represent a study universe, in the REM, each study, whether it has a small or a large sample size, shows a more balanced distribution as it should be represented in the summarized effect (Borenstein et al., 2009; Raudenbush, 2009). In this regard, in the interpretation of the effect sizes, the REM was taken into account. On the other hand, according to Field and Gillett (2010), in the calculation of the effect sizes in the social sciences, REM should be used as a standard rule regardless of whether there is a heterogeneous distribution.

\subsubsection{The reliability of the study}

In meta-analytical studies, some methods are suggested to ensure reliability. Mostly selecting the studies included in the meta-analysis among only published and important studies reveals the case of publication bias. The tendency of including more published studies in meta-analysis and the tendency of researchers to publish only statistically or clinically significant results are defined as publication bias (Greenhouse \& Iyengar, 2009). To decrease or remove publication bias, Rosenthal's Fail-safe Number calculation was conducted (Rosenthal, 1979). The number of missing studies that would bring $\mathrm{p}$ value $>$ alpha is 849 . Due to being the fail-safe number obtained a very high value, it is possible to say that the effect size in this meta-analysis is not affected by publication bias (Cheung \& Slavin, 2013). The $N /(5 k+10)$ formula suggested by Mullen et al. (2001) in the fail-safe number calculation was applied and the result was found to be $N /(5 k+10)=849 /(5.12+10)=849 / 70=12.13$, which is greater than 1 . This result is interpreted as an indicator of lack of publication bias (Mullen, et al., 2001). In addition, the metaanalytical Orwin's Fail-safe Number was calculated as 1296, suggesting that over 1296 studies with a mean risk ratio of 0.001 would need to be added to the analysis before the cumulative effect would become trivial. On the other hand, for the additional studies, when the effect size value is changed from null to 0.005 , the number of additional studies increases to 250 . The findings regarding Rosenthal's and Orwin's Fail-safe Number calculations show the reliability of the metaanalytical processes in the current study.

A funnel plot, which is a scatterplot comparing the measurement of effect sizes with study sizes (Sutton, 2009), is another method used for publication bias detection (Duval \&Tweedie, 2000). It provides a visual summary of the current dataset (Cooper et al., 2009). In a funnel plot, while the effect size value is included in the $X$ axis, $Y$ axis represents study precision (sample size, variance or standard error) (Sterne \& Harbord, 2004). In the absence of bias, the graph looks like an overturned symmetrical funnel (Sterne et al., 2011).

The funnel plot graph given in Figure 2 shows that the majority of the studies included in the research were placed towards the top of the figure. While studies with small standard error values are collected near the upper part of the funnel graph and near the average effect size, studies with large standard error values appear towards the bottom of the graph (Borenstein et al., 2009). 
Figure 2

Adjusted Effect Size Funnel Plot

Funnel Plot of Standard Error by Hedges's $g$

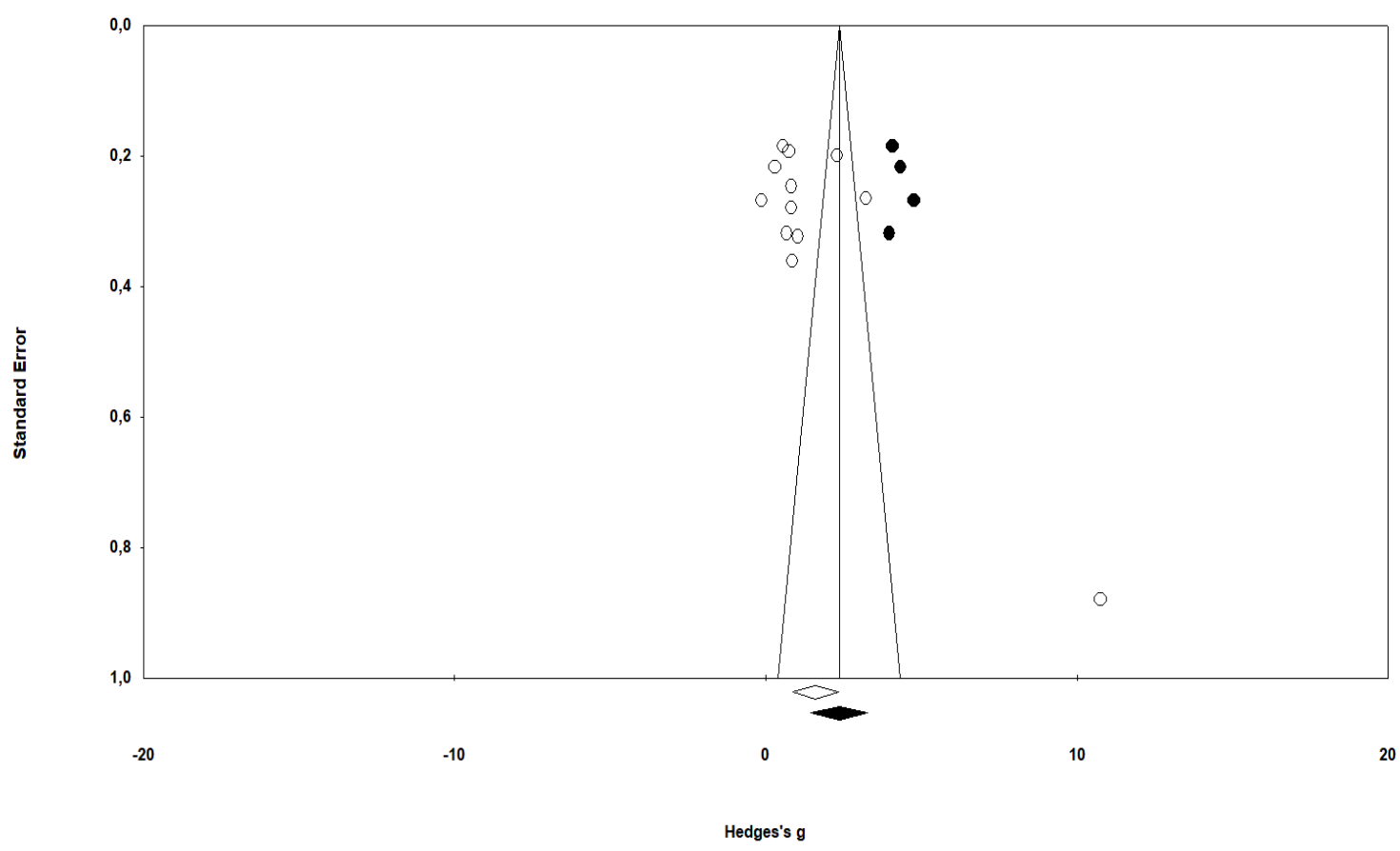

Clustering most of the studies to the left of the mean in the graph is considered as asymmetry suggesting the possibility of publication bias (Borenstein et al., 2009). Therefore, Duval and Tweedie's (2000) trim and fill method was applied and the adjusted funnel plot, where the 4 studies included in the meta-analysis later were shown in black circles was given in Figure 5 . The adjusted effect size value $(g=1.988)$ and the observed effect size value $(g=1.089)$, both of which have the same positive direction and large effect size, were found to be close to each other (see Table 1). Therefore, there is no difference in terms of effect classification. A large difference between the adjusted effect size and observed effect size values may be an indicator of publication bias (Card, 2012). In this condition, the publication bias observed in this study is not at a level to affect the below limit of the graph.

Table 1

Trim and Fill Method of Duval and Tweedie

\begin{tabular}{|c|c|c|c|c|c|}
\hline & Studies Trimmed & Point Estimate & \multicolumn{2}{|c|}{ Confidence Interval } & $Q$ \\
\hline & & & Lower & Upper & \\
\hline $\begin{array}{l}\text { Observed } \\
\text { values }\end{array}$ & & 1.089 & .867 & 2.330 & 272.667 \\
\hline $\begin{array}{l}\text { Adjusted } \\
\text { values }\end{array}$ & 4 & 1.988 & 1.448 & 3.258 & 813.724 \\
\hline
\end{tabular}

Table 1 shows that the adjusted value (1.988) and the observed value (1.089) have the same positive direction and large effect size. Four more studies are required to be added to the metaanalysis for a symmetrical funnel plot. On the other hand, publication bias should be tested statistically as well as visually evaluated. Statistical evaluation is not recommended only when the number of studies is less than 10 (Sterne et al., 2000). Therefore, statistical tests were also employed to determine whether there was publication bias. According to the result of the Egger test (Egger et al., 1997), 95\% confidence interval between -2.223 lower limit and 18.09 upper limit, Intercept $=7.934, t=1.740$ and $p=.11>0.5$. In the Egger test, a " $p$ value of 0.5 or less indicates that asymmetry is statistically significant" (Rothstein et al., 2005, p. 102). Therefore, it was not 
confirmed an asymmetry in the funnel plot by the Egger test. Kendall's tau $b$ coefficient was calculated in Begg and Mazumdar (1994) test. The result being greater than .05 (Tau $b=.36$; $p=.11>.05)$ indicated that the data do not provide sufficient evidence for the presence of publication bias in this sample of studies (Kromrey \& Rendina-Gobioff, 2006).

\subsection{Methodology in the Qualitative Part}

\subsubsection{Design of the study}

The qualitative part of the study contained a thematic analysis to expand the scope of the research by further probing the subject-matter in more details and to supply a more comprehensive information (Batd1, 2017a). Meta-thematic analysis is a method that involves the process of reviewing and re-evaluating the themes consisting of the participants' views on a certain topic determined by various thematic analyzes (Batd1, 2017b). Within the scope of the meta-thematic analysis process, the data obtained by document analysis are interpreted. Document analysis is a form of qualitative research in which documents and resources are examined and interpreted by the researcher in order to give voice and meaning around an evaluation topic in the targeted context (Bowen, 2009).

\subsubsection{Data collection and analysis process}

In the qualitative aspect of the study, 13 studies containing participants' views on infographics were selected among the studies searched within the same databases. Data were collected in accordance with a documentary review through the content analysis and analyzed using the MAXQDA-11 program. The main aim in a content analysis is to reach some concepts and to reveal the relationships between them. For this aim, conceptualizations, from the data of the studies, are made and similarities of the concepts are brought together and coded with certain themes, and after the necessary adjustments, the results are interpreted (Yıldırım \& Şimsek, 2016). To this end, in order to obtain qualitative findings, similar themes and codes were rearranged in a certain harmony and the findings were presented as models. In addition, in order to ensure reliability, corroboration and justification, the statements in the studies where the themes and codes were taken were shown in the text. Direct quotations were originally given with no comment by the researchers to increase the reliability of the study and with study-codes and page numbers (i.e., in the code 6-QI-A-88, "6" code stands for the number of the study; "QI" code refers to Qualitative Infographics; “ $\mathrm{A}$ " code represents Article and " 88 " indicates the quotation's page number).

\subsubsection{Reliability of the meta-thematic process}

In the qualitative dimension of this study, in order to ensure consistency of findings, it is important that the meaningfulness and inter-consistency of codes and themes create integrity. Accordingly, for the inter-rater reliability of the study, agreement coefficient values (Cohen's Kappa statistics) were calculated for giving the coders' agreement (Yıldırım \& Simşek, 2016) and found to be between .788 and .839 as "almost perfect agreement" (see Table 6, Appendix 2).

\section{Findings}

In this section, quantitative and qualitative findings of the study are presented separately. Table 2 represents the descriptive data of the studies included in the meta-analysis. 
Table 2

Descriptive Data of the Studies in the Meta-Analysis

\begin{tabular}{|c|c|c|c|}
\hline Study Variables & & Frequency & Percentage \\
\hline \multirow[t]{4}{*}{ Publication Year $(k=11)$} & 2016 & 2 & $16.6 \%$ \\
\hline & 2017 & 2 & $16.6 \%$ \\
\hline & 2018 & 3 & $25 \%$ \\
\hline & 2019 & 5 & $41.6 \%$ \\
\hline \multirow[t]{3}{*}{ Study Type $(k=11)$} & PhD Dissertations & 1 & $8.3 \%$ \\
\hline & Master's Theses & 5 & $41.6 \%$ \\
\hline & Research Articles & 6 & $50 \%$ \\
\hline \multirow{6}{*}{$\begin{array}{l}\text { The Lesson in which the } \\
\text { experimental study was conducted } \\
(k=11)\end{array}$} & Geography & 3 & $25 \%$ \\
\hline & Science & 3 & $25 \%$ \\
\hline & ELT & 1 & $8.3 \%$ \\
\hline & Social Sciences & 2 & $16.6 \%$ \\
\hline & Information Technology & 2 & $16.6 \%$ \\
\hline & Mathematics & 1 & $8.3 \%$ \\
\hline \multirow{5}{*}{$\begin{array}{l}\text { Duration of the Experimental } \\
\text { Process }(k=11)\end{array}$} & 2-3 Week & 2 & $16.6 \%$ \\
\hline & 4-5 Week & 4 & $33.3 \%$ \\
\hline & 6-7 week & 2 & $16.6 \%$ \\
\hline & 8 and + week & 1 & $8.3 \%$ \\
\hline & Unspecified & 3 & $25 \%$ \\
\hline \multirow[t]{4}{*}{ Grade/ Class Level $(k=11)$} & Primary education & 1 & $8.3 \%$ \\
\hline & Secondary education & 6 & $50 \%$ \\
\hline & High school & 2 & $16.6 \%$ \\
\hline & University & 3 & $25 \%$ \\
\hline
\end{tabular}

The descriptive data of the studies in Table 2 show that there is an increase in the number of experimental studies on the use of infographics in education every year. Of the studies, $16.6 \%$ $(f=2)$ were carried out in $2016,16.6 \%(f=2)$ in $2017,25 \%(f=3)$ in 2018 , and $41.6 \%(f=5)$ in 2019. On the other hand, while $41.6 \%(f=5)$ of the studies were master's theses, $50 \%(f=6)$ were research articles and $8.33 \%(f=1)$ were $\mathrm{PhD}$ dissertations. Of the studies, $25 \%(f=3)$ were regarding the use of infographics in Geography lesson, 25\% $(f=3)$ in Science, $8.3 \%(f=1)$ in English Language Teaching, 16.6\% $(f=2)$ in Social Sciences lessons, $16.6 \%(f=2)$ in Information Technology, and $8.3 \%(f=1)$ in Mathematics. When taking the duration of the implementation of experimental procedures into consideration, the time spent on the most experimental implementations was found to be in the range of $4-5$ weeks $(33.3 \% ; f=4)$. This is followed by the range of $2-3$ weeks $(16.6 \% ; f=2)$ and $6-7$ weeks $(16.6 \% ; f=2)$. In $8.3 \%$ of the studies $(f=1)$, the time allocated to experimental procedures was 8 and above weeks; and in $25 \%(f=3)$, it was unspecified. With regard to grade level, while the most studies were carried out at secondary education level $(50 \% ; f=6)$, the least was conducted at primary education level $(8.3 \% ; f=1)$. Of the rest studies, $25 \%(f=3)$ were carried out at university level, and 16.6\% $(f=2)$ at high school level.

\subsection{Quantitative Findings- Findings of Meta-Analysis}

Table 3 shows the homogeneity value, average effect sizes, and confidence intervals for FEM and REM, as well as the effect sizes of the studies to be included in the meta-analysis. 
Table 3 .

Average Effect Sizes and Lower and Upper Values of Confidence Interval in terms of Effect Model

\begin{tabular}{|c|c|c|c|c|c|c|c|c|c|c|}
\hline \multirow{2}{*}{$\begin{array}{l}\text { Model } \\
\text { type }\end{array}$} & \multirow[t]{2}{*}{$k$} & \multirow{2}{*}{ Hedges' $g$} & \multirow[t]{2}{*}{ SE } & \multicolumn{2}{|c|}{$\begin{array}{l}95 \% \text { Confidence } \\
\text { Interval }\end{array}$} & \multirow[t]{2}{*}{$Q$} & \multirow{2}{*}{$\frac{d f}{11}$} & \multirow[t]{2}{*}{$Z$} & \multirow[t]{2}{*}{$I^{2}$} & \multirow[t]{2}{*}{$p$} \\
\hline & & & & Lower & Upper & & & & & \\
\hline FEM & 12 & 1.090 & .073 & .947 & 1.233 & & & 14.934 & 95.966 & .000 \\
\hline REM & 12 & 1.599 & .373 & .868 & 2.330 & $2 / 2.667$ & & 4.266 & & .000 \\
\hline
\end{tabular}

As given in Table 3, according to REM calculations, the overall effect size was Hedges' $g=1.599$, which is a large effect size according to Cohen's (1992) classification. The standard error was .373 and the upper limit for $95 \%$ of the confidence interval was 2.330 while the lower limit was .868 . When the statistical significance was calculated according to the z-test, it was found to be 4.266 $(p=.000)$.

As a result of the heterogeneity test, the $Q$ statistical value was found to be 272.667 . Due to the $Q$ statistical value's exceeding the critical value of the chi-square distribution $\left(\chi^{2}(.95)=19.67\right)$, the distribution of the effect sizes was confirmed to be heterogeneous. On the other hand, the $I^{2}$ value was found to be $95.966 \%$ indicating a high level of heterogeneity according to the Higgins and Thompson (2002) classification which indicates a considerable heterogeneity from $75 \%$ to 100 . As a result, the value $(g=1.599)$ in the REM shows that the results are in favor of the effectiveness of using infographics on academic achievement in education. The forest plot of the 12 studies included in the research is given in Figure 3.

Figure 3

Forest Plot of the Studies

\begin{tabular}{|c|c|c|c|c|c|c|c|}
\hline \multirow[t]{2}{*}{ Study name } & \multicolumn{7}{|c|}{ Statistics for each study } \\
\hline & $\begin{array}{c}\text { Hedges's } \\
g\end{array}$ & $\begin{array}{l}\text { Standard } \\
\text { error }\end{array}$ & Variance & $\begin{array}{l}\text { Lower } \\
\text { limit }\end{array}$ & $\begin{array}{l}\text { Upper } \\
\text { limit }\end{array}$ & Z-Value & $\mathrm{p}$-Value \\
\hline Dodru, D., 2019 & 3,226 & 0,265 & 0,070 & 2,706 & 3,746 & 12,155 & 0,000 \\
\hline Kokoz, A. 2019 & 0,548 & 0,185 & 0,034 & 0,186 & 0,910 & 2,965 & 0,003 \\
\hline Caka, C. 2018 & 0,297 & 0,217 & 0,047 & $.0,129$ & 0,723 & 1,366 & 0,172 \\
\hline Ozel, E. 2019 & $-0,142$ & 0,269 & 0,072 & $-0,668$ & 0,385 & $-0,528$ & 0,598 \\
\hline Perdahci, N. Z, 2018 & 0,665 & 0,319 & 0,102 & 0,041 & 1,290 & 2,088 & 0,037 \\
\hline Yesiltas, E, \& Cevher, S., 2018 & 1,035 & 0,323 & 0,105 & 0,401 & 1,669 & 3,198 & 0,001 \\
\hline Alrwere, N. S., 2017 & 2,300 & 0,200 & 0,040 & 1,908 & 2,693 & 11,494 & 0,000 \\
\hline Alshehri, M. A. \& Ebaid, M., 2016 & 0,855 & 0,361 & 0,131 & 0,147 & 1,564 & 2,366 & 0,018 \\
\hline Cifci, T., 2016 & 0,752 & 0,193 & 0,037 & 0,373 & 1,131 & 3,886 & 0,000 \\
\hline Yilmaz, A., Yaz, O. V., \&Yuzbasioglu, M. K, 2019 & $19 \quad 10,757$ & 0,879 & 0,772 & 9,034 & 12,479 & 12,241 & 0,000 \\
\hline Karasu, B., 2019 & 0,828 & 0,247 & 0,061 & 0,344 & 1,311 & 3,357 & 0,001 \\
\hline \multirow[t]{2}{*}{ Nwosu Ebere, H. \& Awotua-Efebo, E. B. 2017} & 0,815 & 0,280 & 0,078 & 0,267 & 1,363 & 2,916 & 0,004 \\
\hline & 1,090 & 0,073 & 0,005 & 0,947 & 1,233 & 14,934 & 0,000 \\
\hline
\end{tabular}
Hedges's $\mathrm{g}$ and $95 \% \mathrm{Cl}$

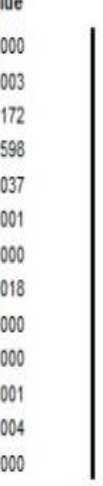

$-4,00$

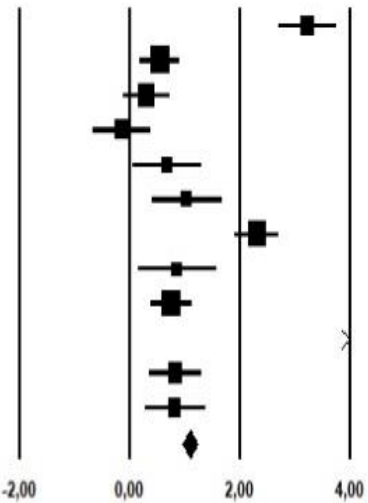

Favours A

Favours B

According to the forest graph given in Figure 3, while Yilmaz et al.'s (2019) study has the widest range of confidence interval, Ozel's (2019) study has the narrowest confidence interval. As a result, except for the study conducted by Ozel (2019), all studies included in this study have a positive effect, which shows that the effectiveness of infographic use is in favor of experimental groups.

\subsubsection{Moderator Analyses}

School grades, implementation periods and school subjects were the moderators of this study. In order to identify the overall effect sizes of the studies included in meta-analysis according to the school grades, the studies were distributed into four groups as, Primary Education, Secondary Education, High School and University. However, the group Primary Education was excluded from the analysis as it included only one study. In this regard, Valentine et al., (2010), took up the 
question “How many studies do you need to do a meta-analysis?' in their study and they explained the minimal number of studies as two.

Table 4

The Results of the moderator analyses

\begin{tabular}{|c|c|c|c|c|c|c|c|c|c|c|}
\hline \multirow[t]{2}{*}{ Moderators } & \multirow[t]{2}{*}{ Groups } & \multicolumn{4}{|c|}{$\begin{array}{c}\text { Effect Size and 95\% Confidence } \\
\text { Interval }\end{array}$} & \multicolumn{2}{|c|}{ Test of Null } & \multicolumn{3}{|c|}{ Heterogeneity } \\
\hline & & $k$ & Hedge's $g$ & Lower & Upper & $Z$ & $p$ & $Q$-value & $\mathrm{df}$ & $p$ \\
\hline \multirow[t]{7}{*}{ School Grades } & $\begin{array}{l}\text { Primary } \\
\text { education }\end{array}$ & 1 & - & - & - & & & & & \\
\hline & $\begin{array}{l}\text { Secondary } \\
\text { education }\end{array}$ & 6 & 2.458 & 1.089 & 3.827 & 3.519 & 0.000 & & & \\
\hline & High school & 2 & 0.752 & -2.520 & 4.024 & 0.450 & 0.652 & & & \\
\hline & University & 3 & 1.140 & -0.755 & 3.035 & 1.179 & 0.238 & & & \\
\hline & Tot. Betw. Overall & 12 & 1.492 & 0.259 & 2.726 & 2.371 & 0.018 & 2.558 & 2 & 0.634 \\
\hline & 2-3 Week & 2 & 0.345 & -1.099 & 1.790 & 0.469 & 0.027 & & & \\
\hline & 4-5 Week & 4 & 1.343 & 0.155 & 2.530 & 2.216 & 0.027 & & & \\
\hline Implementation & 6-7 week & 2 & 0.710 & 0.736 & 2.156 & 0.962 & 0.336 & & & \\
\hline \multirow[t]{6}{*}{ Periods } & 8 and + week & 1 & - & - & - & & & & & \\
\hline & Unspecified & 3 & 1.267 & 0.247 & 2.286 & 2.434 & 0.015 & & & \\
\hline & Tot. Betw. Overall & 12 & 2.616 & 0.299 & 4.933 & 2.213 & 0.027 & 51.683 & 3 & 0.000 \\
\hline & Geography & 3 & 1.501 & -0.284 & 3.285 & 1.648 & 0.099 & & & \\
\hline & Science & 3 & 3.266 & 1.405 & 5.127 & 3.440 & 0.001 & & & \\
\hline & ELT & 1 & - & - & - & & & & & \\
\hline \multirow[t]{5}{*}{ School Subjects } & Social Sciences & 2 & 0.850 & -1.360 & 3.060 & 0.754 & 0.451 & & & \\
\hline & Information & 2 & 0.555 & -1.638 & 2.747 & 0.496 & 0.620 & & & \\
\hline & Technology & & & & & & & & & \\
\hline & Mathematics & 1 & - & - & - & & & & & \\
\hline & Tot. Betw. Overall & 12 & 1.608 & 0.373 & 2.843 & 2.552 & 0.011 & 4.803 & 3 & 0.440 \\
\hline
\end{tabular}

According to the analysis results of the remaining three groups of the school grades, the secondary Education group with a 2.458 value had the highest overall effect size while the High School group with a 0.752 value had the lowest overall effect size. In Table 4 , the $Q_{B}=2.558$ value was detected according to the intergroup heterogeneity test results. Since this value was lower than the $\chi^{2}$ distribution value which was recorded to be as $\chi_{(0.95)}^{2}=5.99$ for 2 degrees of freedom, it can be said that there are no significant differences amongst the inter-groups $(Z=1.233$; $p>0.05)$. This finding shows that the level of academic achievement does not differ in the school grades in which infographics were used.

To determine if the overall effect size of the use of infographics change in accordance with the implementation period, the application durations of infographics within the studies were grouped as $2-3 ; 4-5 ; 6-7 ; 8$ and upper weeks and "Unspecified." The group " 8 and upper" was excluded from the analysis because it included only one study. The remaining four groups were included in the analysis and according to the results, while the lowest value was observed in the "2-3 weeks" group $(g=0.345)$, the highest value was in the " $4-5$ weeks" group $(g=1.343)$. In the intergroup heterogeneity test, the value was found to be $Q_{B}=51.683$. The $\chi^{2}$ distribution value was $\chi_{(0.95)}^{2}=7.82$ for 3 degrees of freedom. Accordingly, the $Q_{B}$ statistical value $\left(Q_{B}=51.683\right)$ was greater than the critical value of the $\chi^{2}$ distribution $\left(\chi_{(0.95)}^{2}=7.82\right)$. Thus, the academic achievement shows changes according to implementation periods of infographics $(Z=0.020$; $p<0.05)$.

To identify the impact of the school subjects on the overall effect size, the studies were grouped as Geography, Science, ELT, Social Sciences, Information Technology, and Mathematics. However, the groups ELT and Mathematics were excluded from the analysis due to including only one study. The remaining four groups were analyzed and the analysis results showed that the highest effect size was observed in Science course $(g=3.266)$ while the lowest effect size was seen in Information Technology course $(g=0.555)$. Additionally, the intergroup heterogeneity test value 
was found as $Q_{B}=4.803$; and, the $Q_{B}$ statistical value $\left(Q_{B}=4.803\right)$ was lower than the critical value of the $\chi^{2}$ distribution $\left(\chi_{(0.95)}^{2}\right) 7.82$. Therefore, no significant differences were found in the effect sizes according to the school subjects; which means academic achievement did not change in terms of the school subjects in which infographics were used $(Z=2.552 ; p>0.05)$.

\subsection{Qualitative (meta- thematic) Findings}

As a result of a detailed analysis of the qualitative data within the context of meta-thematic analysis, three models were generated as "CCognitive Contributions of Infographics" (Figure 4), "Challenges in Using and Development of Infographics" (Figure 5) and, "Suggestions for Application of Infographics" (Figure 6) by gathering into themes and codes.

\subsubsection{Findings related to cognitive contributions of infographics}

The contributions of infographics to the cognitive domains of the participants were modeled and given in Figure 4.

Some codes regarding the use of infographics in the process of teaching-learning were given as "Enabling learners to recognize their learning strategies, Visualizing information clearly in learners' minds, Promoting in-depth understanding, Stimulating engagement, Encouraging attention, Fostering creativity and imagination, Faster way to learn, Promoting big-picture thinking, Providing permanent learning, Contribution to shaping knowledge in learners' minds, Opening minds to new ways of learning, Enabling to shape knowledge in minds, and Helping conceptualize a topic."

Figure 4

Cognitive Contributions of Infographics

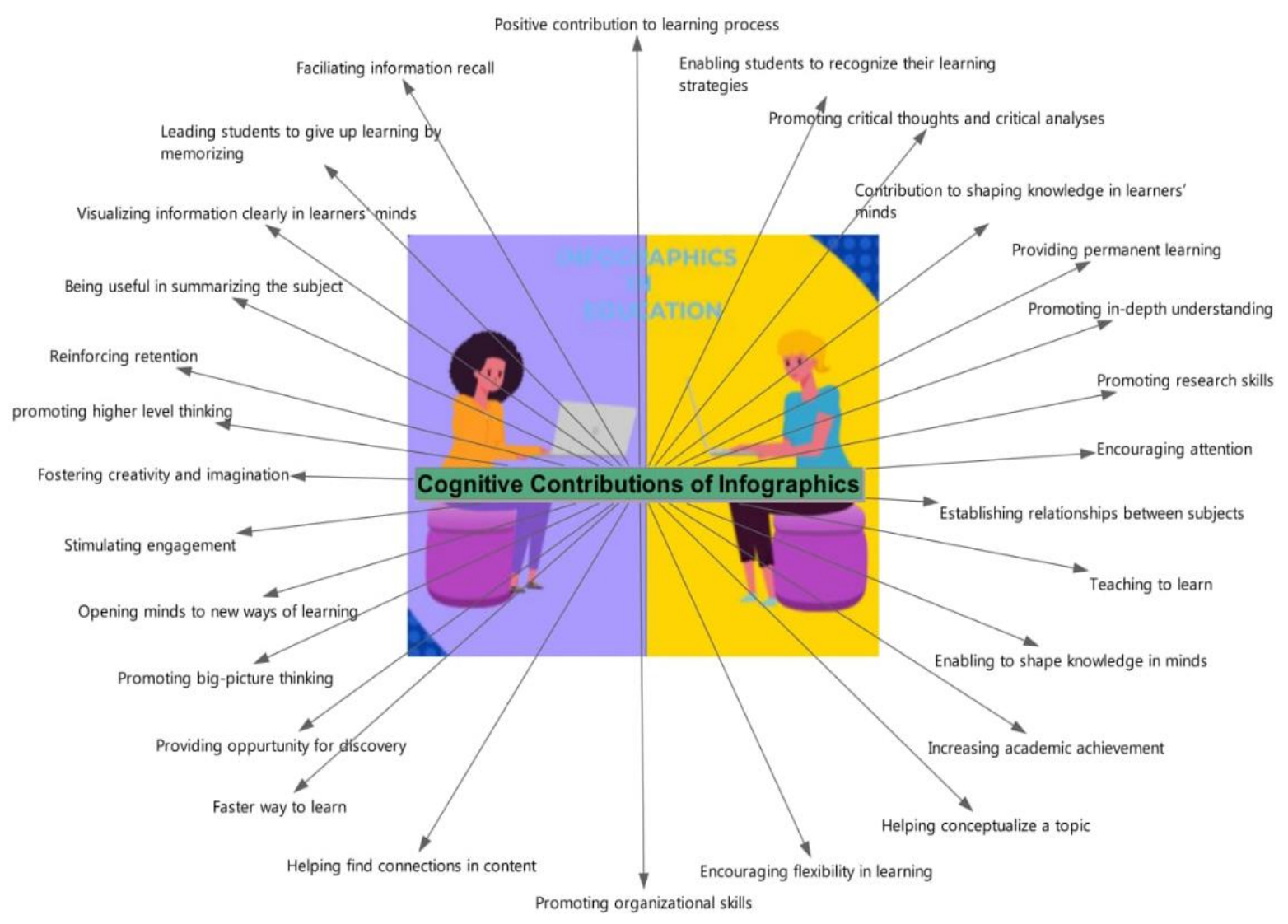

In the form of the relevant codes, the following expressions were taken into account: From the study coded 7-I-PhD-95 "It is an important way to present a large amount of information and provide a quick summary for someone to learn"; from the study coded 4-I-A-506 "Infographics 
clearly visualized the information students studied on" and "Creating an infographic helped shape the information in my mind." On the other hand, the expressions "Creating the infographic helped me better understand how having a simple, visual layout of information can make a topic more interesting to the reader" from the study coded as 1-I-A-171 highlight that infographics are as a means of conveying versatile information in an easy way to understand and conceptualizing a topic. These codes taking part in this model demonstrate that when infographics are involved in the learning process, they have contributed to the participants' cognitive domains in many ways such as facilitating learning, increasing the retention of their learning, developing visual thinking skills, etc.

\subsubsection{Findings regarding challenges in using and development of infographics}

In the meta-thematic analysis of the related studies, it was seen that there were challenges with the use and development of infographics. Therefore, the negative aspects of infographics were discussed in two different dimensions, from the viewpoint of teachers and students, and synthesized with a model given in Figure 5.

Figure 5

Challenges in Using and Development of Infographics

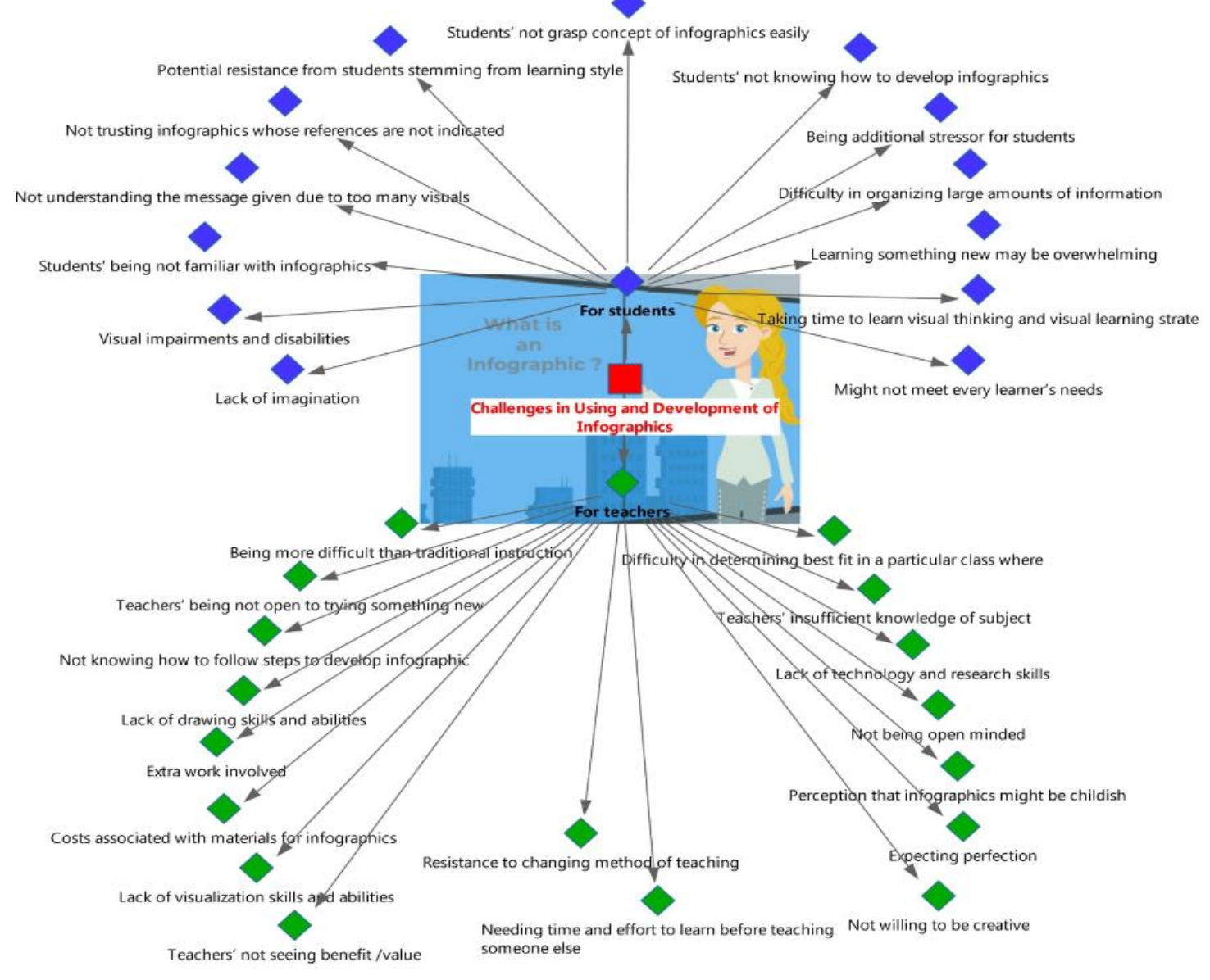

In Figure 5, some codes related to the challenges from the perspective of teachers can be expressed as "Teachers' being not open to trying something new, Extra work and time involved, Being more difficult than traditional instruction, Not knowing how to follow steps to develop infographic, Resistance to changing method of teaching, Teachers' insufficient knowledge of subject, and Lack of visualization skills and abilities." For the creation of the relevant codes, some expressions taken as references from the studies regarding the use of infographics by teachers are especially resistance to changing their teaching methods and not open to doing this. From the relevant studies especially the one emphasizing the challenges of infographics indicates some 
important points (coded as 7-I-PhD-147-258) “...I guess we might have teachers who are not open to making infographics just because it's different and it's not something they were taught...I think some teachers may be resistant. And many of us teach our lessons in the same old routine, you know, preparing something new for us might be like developing a new method or a new way of teaching."

Some codes regarding the challenges from the perspective of students can be expressed as "Students' being not familiar with infographics, Students' not grasping concept of infographics easily, Visual impairments and disabilities, Being additional stressor for students, Students' not knowing how to develop infographics, Lack of imagination, Taking time to learn visual thinking and learning strategies.

To this end, the study coded as 5-I-PhD-141emphasizes that students are not familiar with infographics. Therefore, they have difficulty in finding the right format and design plan to create infographics: "Creating an infographic requires special skills such as design, writing -namely, it requires certain skills in how to organize, visualize and transmit the basic information contained in a complex dataset in design." Moreover, in the study coded as 12-I-A- 252, one of the factors perceived to influence the use of infographics was expressed as not understanding the content in to develop an infographic: "To show current information as an infographic, it is necessary that you should understand the content quite deeply."

\subsubsection{Findings related to suggestions for application of infographics}

In Figure 6, some suggestions obtained from different studies on infographic application were modeled with the relevant codes.

Some codes from the teachers' perspectives are as follows: "It should be understood how to develop an infographic, It should be a significant part of the course, It should be collaborated with other teachers, Additional training for infographics should be provided, and It should be picked the right course/topic for infographics." The statements quoted from the 7-I-PhD-149 coded study emphasizing the importance of being trained on how to develop an infographic are worth paying attention "If I had been more educated on how to develop an infographic before giving it to my students, I would understand that they really need to learn better..." More training for teachers on infographic development might help teachers understand how to develop an infographic. Otherwise, teachers cannot assist students in developing their own infographics "I think if you want students to be able to do something, you must show it to them, model it, to some extent ..." (7I-PhD-218). "Educators should reappraise the suitability of infographics as teaching tools and reexamine their own roles in modeling their practices to students." (5-I-PhD-117). The study coded 12-I- A- 252 highlights the fact that appropriate courses or topics are also important in the use of infographics "I think its [an infographic's] use in chronological knowledge in History lesson may provide high-level learning."

As given in Figure 6, some of the codes regarding suggestions from the perspective of students can be expressed as "It should be provided students with examples/samples of infographics, It should be provided technology training, It should be informed students up front about materials needed, It should be provided tools and resources, and It should be provided help selecting/refining information." The statements in the study coded as 12-I-A-252 "The preliminary stage in infographic development is difficult. Therefore, students should be provided with examples/samples of infographics beforehand" emphasize the suggestions for providing sample materials to students before they prepare infographics. Moreover, the study coded as 2-I-A-22 suggests that the educators should keep up with the current technology for guiding the use of infographics by students in the classroom as a course material. Therefore, this study also contains some suggestions regarding formulating ways and examples to students in order to implement infographics to their future classroom. 
Figure 6

Suggestions for Application of Infographics

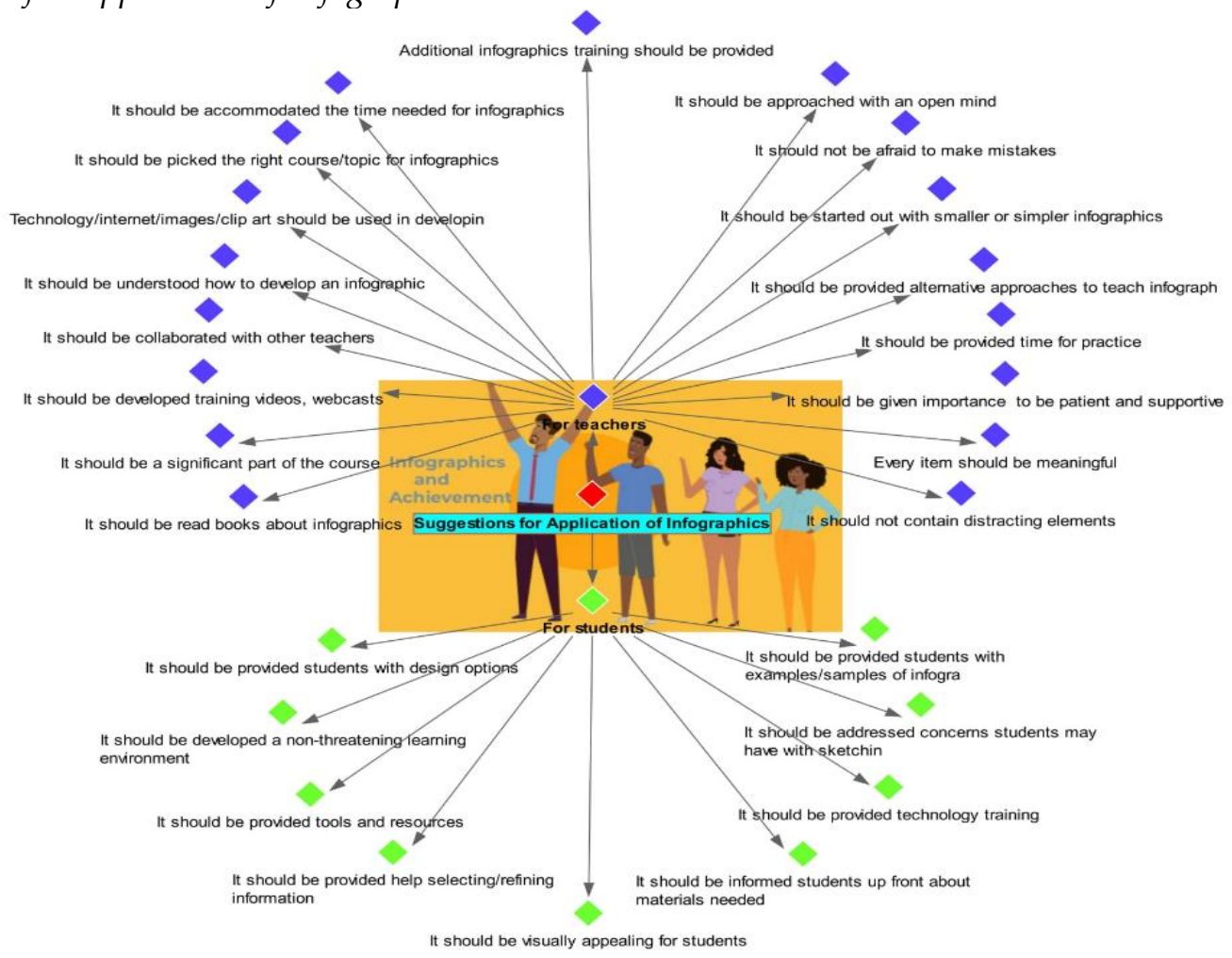

\section{Discussion}

\subsection{Academic Achievement}

In this study, in which 12 experimental studies were synthesized through meta-analysis to reveal the effectiveness of using infographics on achievement in education, the effect size value according to REM calculation was found to be 1.599 (Hedges' $g$ ). This value shows a positive, significant and large effect according to Cohen's (1992) classification. Consistency in the effectiveness of infographics in favor of the experimental group was also supported by other studies included in the analysis (i.e., Alrwere, 2017; Alshehri \& Ebaid, 2016; Caka, 2018; Çifçi, 2016; Doğru, 2019; Karasu, 2019; Kokoz, 2019; Nwosu Ebere \& Awotua-Efebo, 2017; Yesiltas \& Cevher, 2018; Yıldırım, 2018; Yilmaz et al., 2019). Furthermore, consistency in terms of positive impact of infographics on achievement was also supported by the studies that were excluded from the analysis (i.e., Afify, 2018; Akdal, 2019; Al-Mohammadi, 2017; Hassan, 2016; Hertavira, 2019; Ozdal \& Ozdamli, 2017; Saadah, 2019; Waller, 2018; Yarbrough, 2019). Similarly, Noh and Son (2015) stated that infographics contribute positively to achievement and attitude by improving visual thinking skills and improving students' understanding in schools both scientific concepts and communication skills. Baldwin and Wade (2012) also agreed that infographics contribute positively to students' level of interest, understanding and achievement. Conversely, the study, conducted by Ozel (2019) and included in the met-analysis, concluded no significant increase in achievement at all stemming from the use of infographics when compared to the traditional method recommended in the science curriculum. The author stated that this result may be due to the selection of students who do not have a certain level of readiness. However, Alrwele (2017) chose the sample of the study from university students with high readiness. In a similar way, Al- Mohammadi (2017), who used infographics to teach the basics of computer programming and concluded that it facilitates students' learning, selected study group from students with high computer skills. Based on this finding, it is suggested that apart from the effects of infographics on achievement, which are commonly used in the relevant literature, their effects on the other variables such as attitude, motivation, permanence and readiness should be examined. As a result, due to such factors as 
contributing visualization of information to the effective use of time, increasing permanence in learning it can be concluded according to the empirical research available in the literature that the use of infographics has a positive effect on achievement. The findings reached in this study also support this general conclusion.

Additionally, moderator analyses were made within the meta-analytic evaluation to determine if the effectiveness of using infographics in the teaching-learning process with regard to school grades, implementation periods, and school subjects. As a result, changes in the academic achievement were observed in the results of the moderator analysis conducted according to implementation periods of infographics.

\subsection{Implementation Periods of Infographics}

The duration of exposure to data visualization is reported to be an indicator of what to be learnt, interpreted and experienced (Alrwele, 2017; Krum, 2014; Uyan Dur, 2014). The results revealed that infographics were less effective when their implementation periods were limited to 2-3 weeks. On the other hand, the highest overall effect size was seen to be in " $4-5$ weeks" group $(g=1.343)$. In a similar fashion, some studies that investigated the effect of using infographics on learning outcomes found an increase in academic achievement with the use of infographics within a period of 4-5 weeks (i.e.,Caka, 2018; Doğru, 2019; Kokoz, 2019; Yeşiltaş \& Cevher, 2018). Moreover, to promote higher-level thinking, more time is necessary in class to implement the activities (Sparapani, 2000). Howes and Stevenson (2013) asserted that the time-related restrictions allocated for the use of infographics lead to limitations in the development of visual thinking.

\subsection{School Grades and School Subjects (Courses)}

The academic achievement level in school grades in which infographics were used did not show any significant changes. Further findings of the moderator analysis regarding the school subjects indicated no significant differences. The effect of using infographics on the academic achievement level did not change according to different school subjects. It was revealed in this study that experimental studies for the use of infographics in education were conducted in the last 6 years. Thus, it is clear from the results of this study that these limited studies are distributed in certain courses, especially in Geography and Science courses. In Gover's (2017) study, it is stressed that some courses like Mathematics, Science, Statistics and, Biology might be more appropriate for infographic use than a course designed in a non-visual context, such as Writing. In this regard, the author suggests that researchers should be welcome to use infographics whether in the courses which currently utilize information visualizations or in high-level courses that could have a better environment for an infographic use.

\subsection{Cognitive Contributions of Infographics}

Meta-thematic analyzes to reinterpret the relevant themes and codes taking part in the included studies (Batd1, 2019) on infographics were made. A theme regarding the contributions of infographics to the cognitive domain was created and the codes that were collected under this theme were re-evaluated. It has been revealed that infographics are effective in student achievement, enhancing creativity and high-level thinking skills. They facilitate the learning process and provide permanent learning (Akkoyunlu \& Y1lmaz, 2005; Davis \& Quinn, 2014; Hart, 2013; Howes \& Stevenson, 2013; Mol, 2011; Toth, 2013; Yildırım, 2016). Moreover, they also provide a way to visualize information clearly in learners' minds and facilitate to remember the subjects (Callow, 2006; Reyes, 2011; Rosier \& Dyer, 2010; Vanichvasin, 2013; VanMeter \& Garner, 2005). While helping develop such skills as big picture thinking, critical thinking, imagination, discovery, research and, synthesis, infographics have been found to facilitate information recall and reinforce retention of knowledge (Abilock \& Williams, 2014; Davidson, 2014; Gallicano et al., 2014). Using infographics for instructional purposes enables students to recognize their learning strategies, and makes a positive contribution to their learning process as well (Fridman, 2018; Gonzales, 2018). It has also been reported that infographics help students learn how to organize a 
lot of information in a small space (Baldwin \&Wade, 2012; Borkin et al., 2013; Uyan Dur 2014; Yuruk et al., 2019). In addition to all these, the relevant literature has proved that infographics make classroom environments more convenient for students to learn in fun (Alford, 2019; Apriyanti et al., 2020; Dursun\& Odabaş1, 2011; Gover, 2017; Jones et al.,, 2019).

\subsection{Challenges}

In addition to their benefits at the cognitive level, infographics have been reported to have some challenges as well. Some negative aspects from the perspective of teachers were mentioned as extra work involved, not knowing how to follow steps to develop an infographic, being more difficult than traditional instruction, teachers' being not open to trying something new and lack of technology and research skills. The resistance of an instructor to change the way they have taught and the extra time and work required to incorporate infographics were identified by Gover (2017) as the biggest factors facing use of infographics in education. Similarly, despite to many advantages, Chicca and Chunta (2020), claimed that time consuming was one of the disadvantages of infographics. They expressed educators' inexperience in designing infographics and in using the technology as the other disadvantages that were in line with the results of this study. However, technology skills are required to use infographics among educators (Bradshaw \& Porter, 2017; Fullan \& Langworthy, 2014; Sadık, 2008; Shahin, 2020). Accordingly, educators need to learn and understand technologies themselves in order to teach them effectively to students (Hitchcock \& Battista, 2013). On the other hand, unfamiliarity of teachers with infographics and their development steps has the potential to influence the use of infographics as an educational tool. In this context, the findings of the study conducted by Jones et al. (2019), reinforce the importance that instructors learn to use infographics before trying to teach them.

Some negative aspects of infographics from the perspective of students were mentioned as students' not knowing how to develop infographics, being unfamiliar with infographics, difficulty in organizing large amounts of information, taking time to learn visual thinking and visual learning strategies, lack of imagination and potential resistance from students stemming from learning styles. Stones and Gent (2015) emphasized in their work that teachers' efforts on how to organize and visualize information in the use of infographics help both familiarize students with the infographic concept and develop their own infographics. Despite providing students with opportunities to utilize infographics in class presentations, Silverman and Piedmont (2016) claimed that the support given to students in developing their visual learning skills was insufficient. Whereas, "being able to visualize a concept in the mind is a central tenet of infographics" (Gover, 2017, p. 48). Moreover, the results of this study are consistent with the results of meeting the needs of students to improve their visual skills (i.e., Brown, 2014; Gallicano, et al., 2014; Gonzales, 2018; Fridman, 2018). With regard to difficulty in organizing information, Yildırım et al., (2014) observed that the challenges that students struggled with were related to organizing large amounts of information.

\subsection{Suggestions for Application of Infographics}

It may be suggested that infographics for educational use should be designed in accordance with class levels, the right course/topic, learners' expectations, and contribute to students' learning, especially by helping them learn how to associate verbally weighted content with visuals. Additionally, students should be guided and supported with examples/samples of infographics, the time needed for infographics should be accommodated and well-arranged. Moreover, additional infographics training should be provided. As mirrored by outcomes that appear in the literature, instructors should provide examples to students to create infographics and support them instructionally and in accordance with this purpose, students should be given opportunity to develop their own topics (Fridman, 2018; Toth, 2013). While doing this, it is expected that structure and functionality should be considered first and then the decoration should be focused on (Naparin \& Saad, 2017). In the same vein, Abilock and Williams (2014) suggested that students spent a significant amount of time in infographic development and planning processes. In this 
case, after the infographic topic was chosen, teachers were expected to assist students in planning and carrying out the research process. The role and importance of supporting students with feedback in infographic development is also emphasized in the literature (Howes \& Stevenson, 2013; Toth, 2013). In this regard, Davidson (2014) suggests that feedback should be provided to students in a learning environment to present their work related to infographics. In order to maintain the success of application, it is also recommended additional training to use infographic strategies in the classroom. Cano (2011) stated that most people had difficulty in using visual formats effectively, which was due to the lack of training in expressing information through visual communication. Since it is necessary to acquire some skills to use visual tools, capture and reveal ideas and concepts, (Brown, 2014; Cemelelioğlu Altın, 2018; Fridman, 2018), practical applications and teacher training appear necessary. On the other hand, to familiarize students with the infographic concept, students should also be provided with access to infographics outside of the classroom to support them in terms of additional learning, such as web-based applications and instructional videos.

\section{Conclusion and Implications}

Regarded as the educational application of information visualization forms, infographics are on the agenda of educational research due to not only encompassing extant learning strategies and perspectives such as visual thinking, visual learning, visualization but also the potential benefits it can provide for teaching a variety of school subjects. Therefore, this study included a synthesis of the relevant studies conducted within the last six years. Meta-analysis results of 12 studies revealed that educational use of infographics has a positive effect on academic achievement of learners. On the other hand, this conclusion was supported by the data obtained from the qualitative dimension of the studies included in the meta-thematic aspect of this research.

Within the scope of this study, it is possible to mention some implications for future research. In the literature review process, it was observed that academic studies on the use of infographics in education and effective infographic design are limited to descriptive studies (i.e. Dunlap \& Lowenthal, 2016; İslamoğlu et al., 2015; Nuhoğlu-Kibar \& Akkoyunlu, 2014; Vanichvasin, 2013). However, it is possible to say that empirical research on the use of infographics in education and their effects on learning have gained intensity in the literature for the last six years. Therefore, more empirical studies are needed to test the expressed power of infographics as an effective visual communication tool and teaching material. In this regard, we believe that some future experimental research designed to test the effectiveness of infographics in education could probably provide us with important data within various national contexts. An additional implication for future research is the variables which are limited to three in the current study but mentioned in limitations of the study; therefore, revealing the moderating effects of variables could be suggested to future researchers. And last but not least, since the meta-thematic analysis was also included in the scope of this study and the meta-thematic results supported the contributions of infographics to learning, it is suggested that further researchers make use of various methodologies to fully explore the contributions of the use of infographics in education.

\section{Limitations}

The meta-analytic findings of the study should be evaluated carefully together with its limitations. One considerable limitation of the study is to include the studies conducted in education. Another limitation is that the studies included in meta-analysis were not specified with more sub-groups. Therefore, three variables were considered and analyzed. This limitation is due to the limited number of experimental studies that were observed in the published literature on the use of infographics on academic achievement in education and many could not include sufficient data for sub-groups. What's more, the meta-analytic finding of this study is limited to revealing the effect of infographics on academic achievement. However, although the experimental studies carried out to reveal the effect of infographics on reading comprehension (Akdal, 2019), on visual learning 
designing skills (Afify, 2018), on writing skills (Saadah, 2019) have been available in the literature, they were excluded from the scope of this study. Therefore, apart from academic achievement, it should also be revealed the effects of infographics on learners' attitudes, motivation, metacognitive strategies, readiness, permanence, and perceptions.

\section{References}

Note: While the studies in the meta-analysis part are shown with one asterisks $\left({ }^{*}\right)$, the studies in the metathematic analysis are given with two asterisks (**). In addition, the studies taking part in both the metaanalysis and meta-thematic analysis are indicated with $\left({ }^{*} /{ }^{*}\right)$.

Abilock, D. \& Williams, C. (2014). Recipe for an infographic. Knowledge Quest, 43(2), 46-55.

Afify, M. K. (2018). The effect of the difference between infographic designing types (static vs animated) on developing visual learning designing skills and recognition of its elements and principles. International Journal of Emerging Technologies in Learning, 13(9), 204-223. https://doi.org/10.3991/ijet.v13i09.8541

Akdal, Ş. (2019). The effect of the use of infographics to reading comprehension in intertextual readings (Unpublished Master's Thesis). Kırşehir Ahi Evran University, Kırşehir, Turkey.

Akkoyunlu, B. \& Yılmaz, M. (2005). Türetimci çoklu ortam öğrenme kuramı [Generative multimedia learning theory]. Journal of Hacettepe University Education Faculty, 28, 9-18.

**Alford, K. (2019). The rise of infographics: And why teachers and teacher educators should take heed. Teaching/Writing: The Journal of Writing Teacher Education, 7(1) 158-175.

Al-Mohammadi, N. (2017). Effectiveness of using infographics as an approach for teaching programming fundamentals on developing analytical thinking skills for high school students in the city of Makkah in Saudi Arabia. Global Journal of Educational Studies, 3(1), 22- 42. https://doi.org/10.5296/gjes.v3i1.10854

*Alrwele, N.S. (2017). Effects of infographics on student achievement and students' perceptions of the impacts of infographics. Journal of Education and Human Development, 6(3), 104-117. https://doi.org/10.15640/jehd.v6n3a12

*Alshehri, M. \& Ebaid, M. (2017). The effectiveness of using interactive infographic at teaching mathematics in elementary school. British Journal of Education , 4(3), 1-8.

Apriyanti, N., Razak,R. A.,Shaharom, M. S. N., Rahim, S. S. A. \& Halili, S. H. (2020). Needs analysis of infographic media using technology for learning Physics. Malaysian Online Journal of Educational Technology, 8(1), 48-62. https:// doi.org/10.17220/mojet.2020.01.004

Arneson J. B. \& Offerdahl, E. G. (2018). Visual literacy in Bloom: Using Bloom's taxonomy to support visual learning skills. CBE-Life Sciences Education, 17(1), ar7. https://doi.org/10.1187/cbe.17-08-0178

Baldwin, M. \& Wade, S. M. (2012). Improving family and community engagement through sharing data. Briefing paper. Retrieved from https://sedl.org/secc/resources/briefs/improve_family_commun_share/

Bangert-Drowns, R. L. \& Rudner, L. M. (1991). Meta-analysis in educational research. Paper presented to ERIC Clearinghouse on Tests, Measurement, Evaluation, Washington, DC. (ERIC Document Reproduction Service No. ED 339748).

Batdı, V. (2017a). Smart board and academic achievement in terms of the process of integrating technology into instruction: A study on the McA. Croatian Journal of Education, 9(3), 763-801. https://doi.org/10.15516/cje.v19i3.2542

Batdı, V. (2017b). The effect of multiple intelligences on academic achievement: A meta-analytic and thematic study. Educational Sciences: Theory \& Practice, 17, 2057-2092. https:// doi.org/10.12738/estp.2017.6.0104

Batdı, V. (2019). Meta-tematik analiz [Meta-thematic analysis]. In V. Batdı (Ed.), Meta-tematik analiz: Ornek uygulamalar [Meta-thematic analysis: Sample applications] (pp. 10-76). Anı Publication.

Bateman, S., Mandryk, R. L., Gutwin, C., Genest, A., McDine, D. \& Brooks, C. (2010). Useful junk?: The effects of visual embellishment on comprehension and memorability of charts. In E. Mynatt (Ed.) Proceedings of the SIGCHI Conference on Human Factors in Computing Systems (pp. 2573-2582). Association for Computing Machinery.

Begg, C. B. \& Mazumdar, M. (1994). Operating characteristics of a rank correlation test for publication bias. Biometrics, 50(4), 1088-1101. https:/ / doi.org/10.2307/2533446

Borenstein, M. \& Rothstein, H. (1999). Comprehensive meta-analysis. A computer program for research synthesis. Biostat. Inc. 
Borenstein, M., Hedges, L. V., Higgins, J. P. T. \& Rothstein, H. R. (2009). Introduction to meta-analysis (1st ed.). John Wiley \& Sons, Ltd.

Borkin, M. A., Vo, A. A., Bylinskii, Z., Isola, P., Sunkavalli, S., Oliva, A. \& Pfister, H. (2013). What makes a visualization memorable? IEEE Transactions on Visualization and Computer Graphics, 19(12), 2306-2315. https://doi.org/10.1109/TVCG.2013.234

Bowen, G. A. (2009). Document analysis as a qualitative research method. Qualitative Research Journal, 9(2), 27-40. https:// doi.org/10.3316/QRJ0902027

Bradshaw, M. J. \& Porter, S. (2017). Infographics: A new tool for the nursing classroom. Nurse Educator, 42(2), 57-59. https://doi.org/10.1097/NNE.0000000000000316

Brown, S. (2014). The doodle revolution. Penguin Group.

Byrd, V. (2019). Using Bloom's Taxonomy to support data visualization capacity skills. In S. Carliner (Ed.), Proceedings of E-Learn: World Conference on E-Learning in Corporate, Government, Healthcare, and Higher Education (pp. 1039-1053). Association for the Advancement of Computing in Education (AACE).

Callow, J. (2006). Images, politics, and multiliteracies: Using a visual metalanguage. Australian Journal of Language \& Literacy, 29(1), 7-23.

Cano, M. C. M. (2011). Visualizing information graphics: How to design effective charts and graphs (Unpublished Master's thesis). University of Baltimore, the USA.

Card, N. A. (2012). Applied meta-analysis for social science research. The Guilford Press.

${ }^{* *}$ Cemelelioğlu Altın, N. (2018). Data visualization and infographics in design education (Unpublished Doctoral dissertation). Gazi University, Ankara, Turkey.

*/*Caka, C. (2018). Effect of different infographic designs on learning outcomes, cognitive load and motivation (Unpublished Doctoral dissertation). Eskişehir Anadolu University, Eskişehir, Turkey.

Cheung, A. C. K. \& Slavin, R. E. (2016). How methodological features affect effect sizes in education. Educational Researcher, 45(5), 283-292. https:// doi.org/10.3102/0013189X16656615

Chicca, J., \& Chunta, K. (2020). Engaging students with visual stories: using infographics in nursing education. Teaching and Learning in Nursing, 15, 32-36. https://doi.org/10.1016/j.teln.2019.09.003

Cohen, J. (1992). A power primer. Psychological Bulletin, 112(1), 155-159. https://doi.org/10.1037/00332909.112.1.155

Cooper, H., Hedges, L. V. \& Valentine, J. C. (Eds.). (2009). The handbook of research synthesis and metaanalysis.Russell SAGE Publication.

Creswell, J. W. \& Plano Clark, V. L. (2011). Designing and conducting mixed methods research. Sage Publications Ltd.

*Çifçi, T. (2016). Effects of infographics on students' achievement and attitude towards geography lessons. Journal of Education and Learning, 5(1), 154-166. https:// doi.org/10.5539/jel.v5n1p154

Davidson, R. (2014). Using infographics in the science classroom. Science Teacher, 81(3), 34-39.

Davis, M. \& Quinn, D. (2014). Visualizing text: The new literacy of infographics. Reading Today, 31(3), 16-18.

*Doğru, D. (2019). The effect of teaching natural disasters with infographics on student achievement and course attitude in secondary education Geography courses (Unpublished Master's thesis). Sivas Cumhuriyet University, Sivas, Turkey.

${ }^{* *}$ Dunlap, J. C. \& Lowenthal, P. R. (2016). Getting graphic about infographics: Design lessons learned from popular infographics. Journal of Visual Literacy, 35(1), 42-59.

Dursun, Ö. Ö. \& Odabaşı, F. (2011). Çoklu ortam tasarımı [Multimedia design]. Pegem Akademi.

Duval, S. \& Tweedie, R. (2000). Trim and fill: A simple funnel-plot based method of testing and adjusting for publication bias in meta-analysis. Biometrics, 56(2), 455-463.

Educause Learning Initiative (2013). Seven things you should know about infographic creation tools. Author. Retrieved from http://net.educause.edu/ir/library/pdf/ELI7093.pdf

Egger, M., Smith, G. D., Schneider, M. \& Minder, C. (1997). Bias in meta-analysis detected by a simple, graphical test. British Medical Journal, 315, 629-634. https://doi.org/10.1136/bmj.315.7109.629

Ermis, S. (2008). Using graphic organizers to facilitate elementary students' comprehension of informational text. College Reading Association Yearbook, 29, 87-102.

Fadzil, H. M. (2018). Designing infographics for the educational technology course: perspectives of preservice science teachers. Journal of Baltic Science Education, 17(1), 8-18.

Field, A. P. \& Gillett, R. (2010). How to do meta-analysis. British Journal of Mathematical and Statistical Psychology, 63, 665-694. https:// doi.org/10.1348/000711010X502733

**Fridman, L. (2018). Examining the affordances and constraints of using infographics in pre-service teacher education (Unpublished Master's thesis). University of Ontario Institute of Technology, Oshawa, Canada. 
Fullan, M. \& Langworthy, M. (2014). A rich seam how new pedagogies find deep learning. Pearson.

${ }^{*}$ Gallicano, T., Ekachai, D. \& Freberg, K. (2014). The Infographics assignment: A qualitative study of students' and Professionals' perspectives. Public Relations Journal, 8(4), 1-22.

Gangwer, T. (2015, April 18-20). Shifting to visual teaching (Conference Presentation) International Conference of Creativity, Thinking \& Education, University of St. Thomas in Minnesota. https://www.teachthought.com/learning/shifting-visual-teaching/

${ }^{* *}$ Gonzales, L.S. (2018). Aspects of a literacy of infographics: results from an empirical-qualitative study (Unpublished Doctoral dissertation). University of California, the USA.

${ }^{* *}$ Gover, G. B. (2017). Teacher thoughts on infographics as alternative assessment: a post-secondary educational exploration (Unpublished Doctoral dissertation). Eastern Kentucky University, the USA.

Greenhouse, J. \& Iyengar, S. (2009). Sensitivity analysis and diagnostics. Cooper, H. M., \& Hedges, L. (Ed.), The handbook of research synthesis(pp. 417-434). . Russell Sage Foundation.

Hart, G. (2013). Effective infographics: telling stories in the technical communication context. Retrieved from http:/ / techwhirl.com/effective-infographics-telling-stories-in-the-technical-communication-context/

Hassan, H. G. (2016). Designing infographics to support teaching complex science subject: A comparison between static and animated infographics (Unpublished Master's thesis). Iowa State University, Iowa, the USA.

Hedges, L. V. \& Olkin, I. (1985). Statistical methods for meta-analysis. Academic Press.

Helsper, E. J., \& Eynon, R. (2010). Digital natives: where is the evidence?. British Educational Research Journal, 36(3), 503-520. https:// doi.org/10.1080/01411920902989227

Hertavira, D. E. (2019). The effect of using infographics and students' reading interest on their reading comprehension at Sman 16 Pekanbaru (Unpublished Master's thesis). State Islamic University Sultan Syarif in Pekanbaru, Riau, Indonesia.

Higgins, J. P. T. \& Thompson, S. G. (2002). Quantifying heterogeneity in a meta-analysis. Statistics in Medicine, 21, 1539-1558.

Hitchcock, L. I. \& Battista, A. (2013). Social media for professional practice: Integrating twitter with social work pedagogy. The Journal of Baccalaureate Social Work, 18(special issue), 33-45.

Howes, G. \& Stevenson, K. (2013). How can designing infographics in response to an economic problem promote boys creativity? Retrieved from https://www.theibsc.org/uploaded/IBSC/Action_Reseach/AR_201213/Howes_Stevenson_FinalReport.pdf

Islamoglu, H., Ay, O., Ilic, U., Mercimek, B., Donmez, P., Kuzu, A. \& Odabasi, F. (2015). Infographics: A new competency area for teacher candidates. Cypriot Journal of Educational Sciences, 10, 32-39.

Jones, N., Sage, M. \& Hitchcock, L. (2019). Infographics as an assignment to build digital skills in the social work. Journal of Technology in Human Services, 37,1-23. https:// doi.org/10.1080/15228835.2018.1552904

*Karasu, B. (2019). The effect on academic success of formulated $t$-shirt method for teaching scientists' studies in middle school science course (Unpublished Master's thesis). Ağrı İbrahim Çeçen University, Ağrı, Turkey.

Keller, T. \& Tergan, S. O. (2005). Visualizing knowledge and information: An introduction. In S. O. Tergan \& T. Keller (Eds.), Knowledge and Information Visualization Searching for Synergies (1-23). Springer.

*Kokoz, A. (2019). Infographic effects on academic success in Geography teaching (Unpublished Master's thesis). Sivas Cumhuriyet University, Sivas, Turkey.

Kromrey, J. D. \& Rendina-Gobioff, G. (2006). On knowing what we do not know: an empirical comparison of methods to detect publication bias in meta-analysis. Educational and Psychological Measurement, 66(3), 357373. https://doi.org/10.1177/0013164405278585

Krum, R. (2014). Cool infographics: Effective communication with data visualization and design. John Wiley \& Sons.

Lamb, A. \& Johnson, L. (2014). Infographics part 1: Invitations to inquiry. Teacher Librarian, 41(4). 54-58.

Lamb, G. R., Polman, J. L., Newman, A., \& Smith, C. G. (2014). Science news infographics: Teaching students to gather, interpret, and present information graphically. The Science Teacher, 81(3), 25-30.

Lankow, J., Ritchie, J. \& Crooks, R. (2012). Infographics: The power of visual storytelling. John Wiley\& Sons, Inc.

MacQuarrie, A. (2012, July). Infographics in Education. Think Tank. Retrieved from http:// blog.k12.com/2012/07/10/infographics-education

Matrix, S. \& Hodson, J. (2014). Teaching with infographics: Practicing new digital competencies and visual literacies. Journal of Pedagogic Development, 3(2), 17-27.

Meacham, M. (2015). Use infographics to enhance training. Talent Development, 69(8), 76-77.

Meeusah, N. \& Tangkijviwat, U. (2013). Effect of data set and hue on a content understanding of infographic. ACA2013. Thanyaburi: Blooming Color for Life December, 11-14. Retrieved from 
http://www.repository.rmutt.ac.th/bitstream/handle/123456789/1263/EFFECT\%20OF\%20DATA\%20S ET\%20AND\%20HUE\%20ON....pdf?sequence $=1$

Miles, M, B. \& Huberman, A. M. (1994). Qualitative data analysis: An expanded Sourcebook. (2 ${ }^{\text {nd }}$ ed). Sage.

Moher, D., Liberati, A., Tetzlaff, J., Altman, D.G. \& The PRISMA Group (2009). Preferred Reporting Items for Systematic Reviews and Meta-Analyses: The PRISMA Statement. PLoS Medicine, 6(7), 1-6.

Mol, L. (2011). The potential role for infographics in science communication (Unpublished Master's thesis). Biomedical Sciences, Vrije University, Amsterdam, Netherlands

Moorefield-Lang, H. (2011). Infographics: Information gets visual. Information Searcher, 19(3), 15-16.

Mullen, B., Muellerleile, P. \& Bryant, B. (2001). Cumulative meta-analysis: A consideration of indicators of sufficiency and stability. Personality and Social Psychology Bulletin, 27(11), 1450-1462. https://doi.org/10.1177/01461672012711006

Naparin, H. \& Saad, A. B. (2017). Infographics in education: review on infographics design. literacy. Journal of Baltic Science Education, 15, 173-184. https://doi.org/10.5121/ijma.2017.9602

Nesbit, J. C. \& Adesope, O. O. (2006). Learning with concept and knowledge maps: A meta-analysis. Review of Educational Research, 76(3), 413-448.

Noh, S. \& Son, J. (2015). The effect of physics instruction using infographics based on visual thinking in high school. Journal of the Korean Association for Science Education, 35, 477-85. https://doi.org/10.14697/jkase.2015.35.3.0477

Nuhoğlu Kibar, P. \& Akkoyunlu, B. (2014, October 20- 23). A new approach to equip students with visual literacy skills: use of infographics in education. Serap K., Sonja S., Esther, G., Diane M. and Ralph C. (Eds.). In Information literacy lifelong learning and digital citizenship (pp. 456-465). Switzerland: Springer International Publishing,.

${ }^{*}$ Nwosu Ebere,H. \& Awotua-Efebo E. B.(2017). Infographics and its effects on pre-service teachers' academic achievement and attitude towards media system. International Journal of Quantitative and Qualitative Research Methods, 5(3), 27-36.

Oetting, J. (2015, February). The science behind why our brains crave infographics (In an Infographic). Agency Post. Retrieved from http://blog.hubspot.com/agency/science-brainscrave-infographics. https:// doi.org/10.1007/s11423-007-9060-7

Ozdamli, F., Kocakoyun, S., Sahin, T. \& Akdag, S. (2016). Statistical reasoning of impact of infographics on education. Procedia Computer Science, 102, 370-377. https:/ / doi.org/10.1016/j.procs.2016.09.414

${ }^{*}$ Ozel, E. (2019). The effect of the visual education material infographics on academic success in science teaching (Unpublished Master's thesis). Bayburt University, Bayburt, Turkey.

${ }^{* *}$ Ozdal, H. \& Ozdamli, F. (2017). The effect of infographics in mobile learning: Case study in primary school. Journal of Universal Computer Science, 23(12), 1256-1275,

Petticrew, M. \& Roberts, H. (2006). Systematic reviews in the social sciences. Blackwell Publishers Ltd.

**Polman, J. L. \& Gebre, E. H. (2015). Towards critical appraisal of infographics as scientific inscriptions. Journal of Research in Science Teaching, 52(6), 868-893.

Quispel, A., Maes, A. \& Schilperoord, J. (2018). Information visualization for general audience: the designer's perspective. Arts, 7(4), 72. https://doi.org/10.3390/arts7040072.

Raudenbush, S. W. (2009). Analyzing effect sizes: Random-effects models. In H. Cooper, L. V. Hedges \& J. C. Valentine (Eds.), The handbook of research synthesis and meta-analysis (pp. 295-315). Russell Sage Foundation.

Reavy, M. (2003). Rules and the real world an examination of information graphics in Time and Newsweek. Visual Communication Quarterly, 10(4), 4-10.

Reyes, E. (2011). Connecting knowledge for text construction through the use of graphic organizers. Colombian Applied Linguistics Journal, 13(1), 7-19.

Rosenthal, R. (1979). The file drawer problem and tolerance for null results. Psychological Bulletin, 86(3), 638641. https://doi.org/10.1037/0033-2909.86.3.638

Rosier, J. \& Dyer, P. K. (2010). Visual literacy: A necessary skill for planning graduates? Social Alternatives, 29(4), 64-68.

Rothstein, H. R., Sutton,A. J. \& Borenstein, M. (2005). Publication bias in meta-analysis: Prevention, assessment and adjustments. John Wiley \& Sons, Ltd.

$\mathrm{Ru}$, G. \& Ming, Y. C. (2014, September 29-30). Infographics applied in design education [Conference Presentation]. IEEE Workshop on Advanced Research and Technology in Industry Applications (WARTIA) 2014, Ottawa, Canada. https:// doi.org/10.1109/WARTIA.2014.6976439 
Saadah, A. (2019). The effect of infographic media on students' writing skill (Graduating paper). State Islamic Institute of Salatiga (IAIN Salatiga), in Salatiga, Indonesia. http:// perpus.iainsalatiga.ac.id/lemari/fg/free/pdf/?file=http://perpus.iainsalatiga.ac.id/g/pdf/publ ic/index.php/?pdf=6370/1/ gabungan\%20skripsi

Sadik, A. (2008). Digital Storytelling: A meaningful technology-integrated approach for engaged student learning. Educational Technology Research and Development, 56, 487-506. https://doi.org/10.1007/s11423008-9091-8

Schrock, K. (2014). Infographics as a creative assessment. Retrieved from https://www.schrockguide.net/infographics-as-an-assessment.html.

Schulten, K. (2010). Teaching with infographics: Places to start. The Learning Network: Teaching $\mathcal{E}$ Learning with The New York Times. Retrieved from http://learning.blogs.nytimes.com/2010/08/23/teaching-withinfographics-places-to-start

Shahin, A. (2020). Employing infographics based on tablet applications to improve professional competence in the light of the digital transformation of education technology specialists. International Journal of $\begin{array}{lllll}\text { Instructional Technology and Educational } & \text { Studies, } & \text { 7(1), }\end{array}$ https:// doi.org/10.21608/IHITES.2020.28769.1006

Shatri, K. \& Buza, K. (2017). The use of visualization in teaching and learning process for developing critical thinking of students. European Journal of Social Sciences Education and Research, 9, 71-74.

Silverman, K. N., \& Piedmont, J. (2016). Reading the big picture: A visual literacy curriculum for today. Knowledge Quest, 44(5), 32-37.

Smiciklas, M. (2012). The power of infographics: Using pictures to communicate and connect with your audiences. Pearson Education/Que.

Sparapani, E. F. (2000). The effect of teaching for higher-level thinking: an analysis of teacher reactions. Education, 121(1), 80-89.

Sterne, J. A. \& Harbord, R. M. (2004). Funnel plots in meta-analysis. The Stata Journal: Promoting Communications on Statistics and Stata, 4(2), 127-141. https:/ / doi.org/10.1177/1536867X0400400204

Sterne, J. A. C., Sutton, A. J., Ioannidis, J. P. A., Terrin, N., Jones, D. R., Lau, J., ... Higgins, J. P. T. (2011). Recommendations for examining and interpreting funnel plot asymmetry in meta-analyses of randomised controlled trials. British Medical Journal, 343(1), d4002-d4002. https://doi.org/10.1136/bmj.d4002

Sterne, J., Gavaghan, D. J. \& Egger, M. (2000). Publication and related bias in meta-analysis: Power of statistical tests and prevalence in the literature. Journal of Clinical Epidemiology, 53,1119-129.

Stones, C. \& Gent, M. (2015). The 7 graphic principles of public health infographic design. Retrieved from http://www.improvementacademy.org

Sundeen, T. H. (2007). So what's the big idea? Using graphic organizers to guide writing for secondary students with learning and behavioral issues. Beyond Behavior, 16(3), 29-34.

Sutton, A. J. (2009). Publication bias. In H. Cooper, L. V. Hedges, \& J. C. Valentine (Eds.) The handbook of research synthesis and meta-analysis (pp. 435-452).: Russell Sage Foundation.

Toth, C. (2013). Revisiting a genre: Teaching infographics in business and professional communication courses. Business Communication Quarterly, 76(4), 446-457.

Uyan Dur, B. I. (2014). Data visualization and infographics in visual communication design education at the age of information. Journal of Arts and Humanities, 3(5), 39-50.

Valentine, J., Pigott, T. \& Rothstein, H. (2010). How many studies do you need? A primer on statistical power for meta-analysis. Journal of Educational and Behavioral Statistics, 35, 215-247. https://doi.org/10.3102/1076998609346961

Vanichvasin, P. (2013). Enhancing the quality of learning through the use of infographics as a visual communication tool and learning tool. Cooperation or Competition (pp. 135-142). http://www.icqa2014.com/downloads/Proceeding_29.pdf\#page=135

VanMeter, P. \& Garner, J. (2005). The promise and practice of learner-generated drawing: Literature review and synthesis. Educational Psychology Review, 17(4), 285-325. https://doi.org/10.1007/s10648-005-8136-3

Waller, K. (2018). The effect of infographics on recall of information about genetically modified foods (Unpublished Master's thesis). Texas Tech University, Texas, the USA.

Ware, C. (2012). Information visualization: Perception for design. Elsevier.

Yarbrough, J. R. (2019). Infographics: in support of online visual learning. Academy of Educational Leadership Journal, 23(2), 1-15. Retrieved from https://www.abacademies.org/articles/Infographics-in-support-ofonline-visual-learning-1528-2643-23-2-135.pdf 
*Yeşiltaş, E. \& Toros, S. (2016). The effectiveness of using interactive infographic in Social studies teaching. Journal of ZfWT , 10(3), 218-231.

**Yldırım, S. (2016). Infographics for educational purposes: their structure, properties and reader approaches. TOJET: The Turkish Online Journal of Educational Technology, 15(3), 98-110.

** Yıldırım, S., Yıldırım, G., Çelik, E. \& Aydın, M. (2014). Bilgi grafiği (infografik) oluşturma süreci üzerine yönelik öğrenci görüssleri [Student views on the process of creating an infographic]. Journal of Research in Education and Teaching, 3(4), 247-255.

*Ylldrrm, Y. S. (2018). The impact of the use of interactive infographics in education on the achievement, attitude and motivation of students (Unpublished master's thesis). Mimar Sinan Güzel Sanatlar University, İstanbul, Turkey.

Yıldırım, A. \& Simsek, H. (2016). Sosyal bilimlerde nitel arastırma yöntemleri [Qualitative research methods in the social sciences]. Seckin Publishing.

*Yılmaz, A., Yaz, Ö.V. \& Yüzbaşığlu, M.K. (2019). The effect of infographic use on the students' academic success and permanence in the teaching of basic machinery unit. Journal of Current Researches on Social Sciences (JoCReSS),9(3), 123-129. https:// doi.org/10.26579/jocress-9.3.8

${ }^{* *}$ Yuruk, S. E. , Yılmaz, R. M. \& Bilici, S. (2019). An examination of postgraduate students' use of infographic design, metacognitive strategies and academic achievement. Journal of Computing in Higher Education, 31, 495-513. https://doi.org/10.1007/s12528-018-9201-5

Wulandari, A. (2013). The ICT usage to enhance regional spatial plan coordination in metropolitan Bandung (Unpublished Master's Thesis). Regional and City Planning, Graduate Program, Institut Teknologi Bandung [Bandung Institute of Technology].

\section{Appendix 1}

The Meta-Analysis Data Collection Form

\begin{tabular}{|c|c|c|c|c|c|c|c|}
\hline & $\begin{array}{l}\text { Studies } \\
\text { (Author, Year) }\end{array}$ & $\begin{array}{l}\text { Study } \\
\text { Type }\end{array}$ & $\begin{array}{l}\text { Number of } \\
\text { participants }\end{array}$ & Course/ Field & $\begin{array}{l}\text { Class } \\
\text { /Grade }\end{array}$ & $\begin{array}{l}\text { Application } \\
\text { period }\end{array}$ & $\begin{array}{c}\text { Effect } \\
\text { size }\end{array}$ \\
\hline \multirow[t]{2}{*}{1} & \multirow[t]{2}{*}{ Doğru (2019) } & Master's & TG: 65 & \multirow[t]{2}{*}{ Geography } & \multirow{2}{*}{$\begin{array}{l}\text { Secondary } \\
\text { education }\end{array}$} & \multirow[t]{2}{*}{5 Weeks } & \multirow[t]{2}{*}{3.226} \\
\hline & & Thesis & CG: 65 & & & & \\
\hline \multirow[t]{2}{*}{2} & \multirow[t]{2}{*}{ Kokoz (2019) } & Master's & TG: 60 & \multirow[t]{2}{*}{ Geography } & High & \multirow[t]{2}{*}{4 Weeks } & \multirow[t]{2}{*}{0.548} \\
\hline & & Thesis & CG: 60 & & school & & \\
\hline \multirow[t]{2}{*}{3} & \multirow[t]{2}{*}{ Caka (2018) } & $\mathrm{PhD}$ & TG: 42 & \multirow{2}{*}{$\begin{array}{l}\text { Information } \\
\text { Technologies }\end{array}$} & University & \multirow[t]{2}{*}{4 Weeks } & \multirow[t]{2}{*}{0.297} \\
\hline & & Dissertation & CG:42 & & & & \\
\hline \multirow[t]{2}{*}{4} & \multirow[t]{2}{*}{ Ozel (2019) } & Master's & TG: 27 & \multirow[t]{2}{*}{ Science } & Secondary & \multirow[t]{2}{*}{2 Weeks } & \multirow[t]{2}{*}{-0.142} \\
\hline & & Thesis & CG: 27 & & education & & \\
\hline \multirow[t]{2}{*}{5} & \multirow[t]{2}{*}{ Yıldırım (2018) } & Master's & TG: 20 & \multirow[t]{2}{*}{ Social Sciences } & Secondary & \multirow[t]{2}{*}{6 Weeks } & \multirow[t]{2}{*}{0.665} \\
\hline & & Thesis & CG:20 & & education & & \\
\hline \multirow[t]{2}{*}{6} & Yesiltas \& & Research & TG:22 & \multirow[t]{2}{*}{ Social Sciences } & Secondary & \multirow[t]{2}{*}{4 Weeks } & \multirow[t]{2}{*}{1.035} \\
\hline & Cevher (2018) & Article & CG:20 & & education & & \\
\hline \multirow[t]{2}{*}{7} & Alrwere (2017) & Research & TG:83 & \multirow[t]{2}{*}{ Language } & University & \multirow{2}{*}{$\begin{array}{c}\text { Not } \\
\text { specified }\end{array}$} & 2.300 \\
\hline & & Article & CG:82 & & & & \\
\hline 8 & Alshehri \& & Research & TG: 15 & Mathematics & Primary & Not & 0.855 \\
\hline & Ebaid (2016) & Article & CG: 17 & & education & specified & \\
\hline 9 & Çifçi (2016) & Research & TG:56 & Geography & High & 6 Weeks & 0.752 \\
\hline & & Article & CG:57 & & school & & \\
\hline 10 & Yilmaz et al. & Research & TG:40 & Science & Secondary & 8 Weeks & 10.757 \\
\hline & (2019) & Article & CG:40 & & education & & \\
\hline 11 & Karasu (2019) & Master's & TG:60 & Science & Secondary & 2 Weeks & 0.828 \\
\hline & & Thesis & CG:49 & & education & & \\
\hline 12 & Nwosu Ebere \& & Research & TG:26 & Information & University & Not & 0.815 \\
\hline & $\begin{array}{l}\text { Awotua-Efebo } \\
\text { (2017) }\end{array}$ & Article & CG:28 & Technologies & & & \\
\hline
\end{tabular}

Note. CG: Control group; TG: Treatment group 


\section{Appendix 2}

Cohen Kappa Values of the Themes in the Study

Effects of Infographics in Education

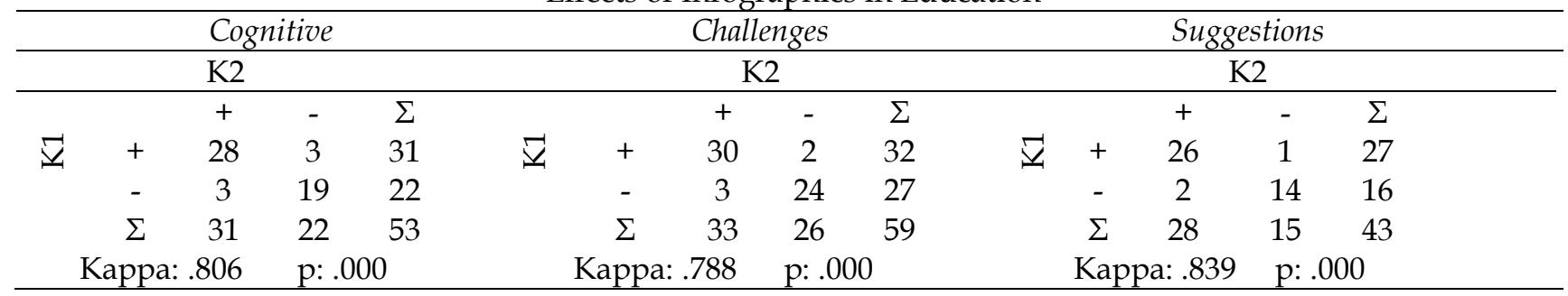

